OPEN ACCESS

Edited by: Kian Mau Goh,

Universiti Teknologi Malaysia, Malaysia

Reviewed by:

Alexander V. Lebedinsky,

Winogradsky Institute of Microbiology,

Russia

Jeremy Dodsworth

California State University, USA

Rup Lal,

University of Delhi, India

*Correspondence:

María-Isabel González-Siso migs@udc.es

Specialty section:

This article was submitted to

Extreme Microbiology,

a section of the journal

Frontiers in Microbiology

Received: 28 July 2016 Accepted: 12 September 2016 Published: 27 September 2016

Citation:

DeCastro M-E, Rodríguez-Belmonte E and González-Siso M-I (2016)

Metagenomics of Thermophiles with a

Focus on Discovery of Novel Thermozymes.

Front. Microbiol. 7:1521 doi: 10.3389/fmicb.2016.01521

\section{Metagenomics of Thermophiles with a Focus on Discovery of Novel Thermozymes}

\author{
Maria-Eugenia DeCastro, Esther Rodríguez-Belmonte and María-Isabel González-Siso * \\ Grupo EXPRELA, Centro de Investigacións Científicas Avanzadas (CICA), Departamento de Bioloxía Celular e Molecular, \\ Facultade de Ciencias, Universidade da Coruña, A Coruña, Spain
}

Microbial populations living in environments with temperatures above $50^{\circ} \mathrm{C}$ (thermophiles) have been widely studied, increasing our knowledge in the composition and function of these ecological communities. Since these populations express a broad number of heat-resistant enzymes (thermozymes), they also represent an important source for novel biocatalysts that can be potentially used in industrial processes. The integrated study of the whole-community DNA from an environment, known as metagenomics, coupled with the development of next generation sequencing (NGS) technologies, has allowed the generation of large amounts of data from thermophiles. In this review, we summarize the main approaches commonly utilized for assessing the taxonomic and functional diversity of thermophiles through metagenomics, including several bioinformatics tools and some metagenome-derived methods to isolate their thermozymes.

Keywords: metagenomics, thermophiles, thermozymes, bioinformatics, NGS

\section{INTRODUCTION}

Thermophiles (growing optimally at $50^{\circ} \mathrm{C}$ or higher), extreme thermophiles $\left(65-79^{\circ} \mathrm{C}\right)$ and hyperthermophiles (above $80^{\circ} \mathrm{C}$ ), categories defined per Wagner and Wiegel (2008), are naturally found in various geothermally heated regions of Earth such as hot springs and deep-sea hydrothermal vents. They can also be present in decaying organic matter like compost and in some man-made environments. Besides the high temperatures, many of these environments are characterized by extreme $\mathrm{pH}$ or anoxia. The adaptation to these harsh habitats explains the high genomic and metabolic flexibility of microbial communities in these ecosystems (Badhai et al., 2015) and makes thermophiles and their thermostable proteins very suitable for some industrial and biotechnological applications. Therefore, screening for novel biocatalysts from extremophiles has become a very important field. In the last few years, novel thermostable polymerases (Moser et al., 2012; Schoenfeld et al., 2013), beta-galactosidases (Wang et al., 2014), esterases (Fuciños et al., 2014), and xylanases (Shi et al., 2013), among others, have been described and characterized, opening a new horizon in biotechnology.

Apart from the bioprospecting purposes, the analysis of these high-temperature ecosystems and their inhabitants can improve our understanding of microbial diversity from an ecological point of view and increase our knowledge of heat-tolerance adaptation (Lewin et al., 2013). Additionally, the study of thermophiles provides a better comprehension about the origin and evolution of earliest life, as they are considered to be phenotypically most similar to microorganisms present on the primitive Earth (Farmer, 1998; Stetter, 2006). In addition to the bacterial and archaeal communities, 
there is an increasing interest in the study of the viral populations living in high-temperature ecosystems, as viruses are reported to be the main predators of prokaryotes in such environments (Breitbart et al., 2004), participating in the biogeochemical cycles and being important exchangers of genetic information (Rohwer et al., 2009).

The first studies of these extremophiles required their cultivation and isolation (Morrison and Tanner, 1922; Brock and Freeze, 1969; Fiala and Stetter, 1986; Prokofeva et al., 2005; De la Torre et al., 2008). Although these techniques have been improved (Tsudome et al., 2009; Pham and Kim, 2012), the growth of thermophiles under laboratory conditions is still a limitation for the insights into the microbial diversity. The evolution of high-throughput DNA sequencing has enabled the development and improvement of metagenomics: the genomic analysis of a population of microorganisms (Handelsman, 2004). Different high-temperature ecosystems like hot springs (Schoenfeld et al., 2008; Gupta et al., 2012; Ghelani et al., 2015; López-López et al., 2015b; Sangwan et al., 2015), deserts (Neveu et al., 2011; Fancello et al., 2012; Adriaenssens et al., 2015), compost (Martins et al., 2013; Verma et al., 2013), hydrocarbon reservoirs (de Vasconcellos et al., 2010; Kotlar et al., 2011), hydrothermal vents (Anderson et al., 2011, 2014), or a biogas plant (Ilmberger et al., 2012) have been analyzed using this metagenomic approach. These whole community DNA based studies were initially focused to answering the question "who are there" and now have shifted to finding out "what are they doing," allowing us the access to the natural microbial communities and their metabolic potential (Kumar et al., 2015).

\section{DIVERSITY ANALYSIS OF THERMOPHILES}

\section{Targeted Metagenomics}

The universality of the 16S rRNA genes makes them an ideal target for phylogenetic analysis and taxonomic classification (Olsen et al., 1986). Schmidt et al. (1991) were the pioneers in performing a community characterization based on metagenome amplified 16S rRNA genes. Since then, the diversity of other natural microbial communities started to be studied using this approach. Jim's Black Pool hot spring, in Yellowstone National Park (YNP), is reported to be the first metagenome-derived analysis of a high-temperature environment based on 16S rRNA gene profiling (Barns et al., 1994).

Initially, these studies required the amplification of the 16S rRNA genes followed by either denaturing gradient gel electrophoresis (DGGE, Muyzer et al., 1993) and sequencing or by cloning of the amplicons. In this case, the libraries obtained were screened using direct Sanger sequencing or restriction fragment length polymorphism (RFLP) analysis (Liu et al., 1997; Baker et al., 2001), to select and sequence those clones with unique patterns (Figure 1). As an example, the effect of $\mathrm{pH}$, temperature, and sulfide in the hyperthermophilic microbial communities living in hot springs of northern Thailand was determined with the amplification of complete 16S rRNA genes followed by DGGE separation and sequencing (Purcell et al., 2007). In a different study, RFLP analysis and sequencing of clones with unique RFLP patterns was used to reveal the presence of abundant novel Bacteria and Archaea sequences in a 16S rRNA gene clone library prepared from the $55^{\circ} \mathrm{C}$ water and sediments of Boiling Spring Lake in California, USA (Wilson et al., 2008).

With the development of next generation sequencing (NGS) technologies, more samples can be analyzed at lower sequencing cost and time, improving the production of $16 \mathrm{~S}$ rRNA genebased biodiversity studies. Additionally, the use of NGS allows to recover more information about the taxonomy of the sample, as reflected by Song et al. (2013), who obtained greater detail in the community structures from 16 Yunnan and Tibetan hot springs with high throughput 454-pyrosequencing than previous studies using conventional clone library and DGGE (Song et al., 2010). These analyses often rely on a partial sequence of $16 \mathrm{~S}$ rRNA genes, as the read length of most NGS platforms is relatively short. For this purpose, primers designed for amplification of variable regions of $16 \mathrm{~S}$ rRNA, like the V4-V8 (Hedlund et al., 2013; Huang et al., 2013), or the V3-V4 (Chan et al., 2015) are used. In the last few years, a high amount of extreme temperature environments have been analyzed with this procedure, especially hot springs, some of which are summarized in Table 1. Thanks to this strategy, a large number of $16 \mathrm{~S}$ rRNA sequences have been produced and deposited in public databases like the Ribosomal Database Project (RDP, Cole et al., 2014) or the SILVA database (Quast et al., 2013).

Even when the process of generating and sequencing the libraries is relatively fast, this PCR-based approach is biased due to limitations of primers, PCR artifacts like chimeras (Ashelford et al., 2005) and inhibitors that could be present in the sample hindering the amplification (Urbieta et al., 2015). Although there are some previous studies focused on primer design to acquire a high coverage rate (Wang and Qian, 2009), difficulties of the primers in recognizing all the $16 \mathrm{~S}$ rRNA sequences have been described (Cai et al., 2013), leading to the unequal amplification of species $16 \mathrm{~S}$ rRNA genes. Furthermore, analysis of $16 \mathrm{~S}$ rRNA sequences can result in misidentification of the taxonomy, as closely related species may harbor nearly identical 16S rRNA genes. In addition, an overestimation of the community diversity could occur since sporadic cases of distant horizontal transfer of the 16S rRNA gene have been inferred from comparisons of these genes within and between individual genomes (Yap et al., 1999; Acinas et al., 2004).

The most used taxonomically informative genomic marker in targeted metagenomics is $16 \mathrm{~S}$ rRNA, but there are other signature sequences that have been used to study the diversity of thermophiles such as internal transcribed spacer regions (ITS, Ferris et al., 2003) or 18S rRNA genes (Wilson et al., 2008), as well as different protein-coding genes such as aox $\mathrm{B}$ gene fragment, which encodes the catalytic subunit of As(III) oxidase, employed by Sharma et al. (2015) in combination to $16 \mathrm{~S}$ rRNA to assess the microbial diversity of the Soldhar hot spring in India.

Apart from the above mentioned amplicon-targeting strategy, in some studies a sequence capture technique coupled with NGS is driven to enrich the targeted sequences present in the metagenome. Captured metagenomics involves custom-designed hybridization-based oligonucleotide probes that hybridize with the metagenomic libraries followed by the sequencing of the probe-bound DNA fragments. Denonfoux et al. (2013) firstly 


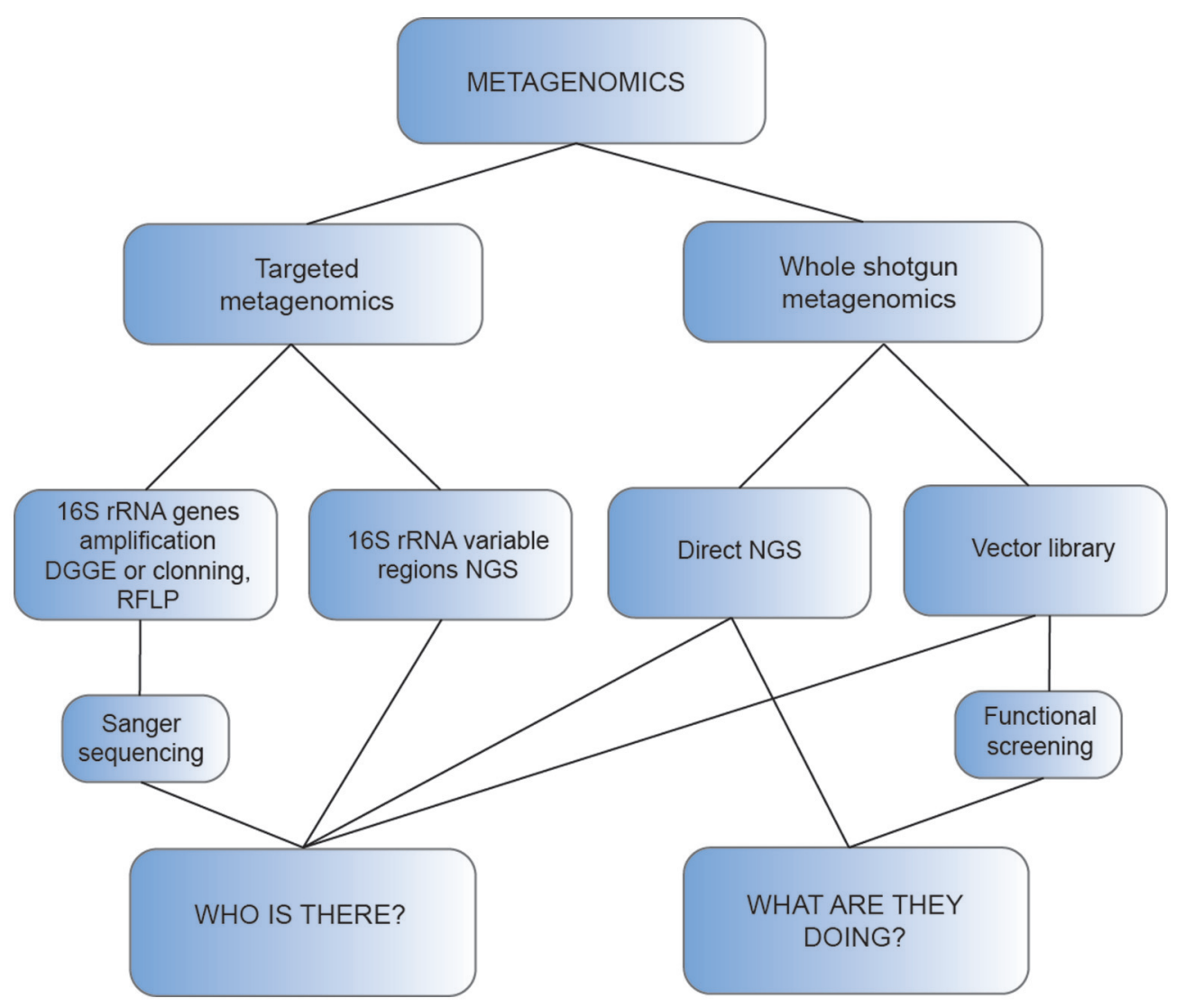

FIGURE 1 | Schematic representation of the main approaches used for metagenomic analysis of thermophiles.

TABLE 1 | Examples of hot springs studied using the amplification of the variable regions of 16S rRNA.

\begin{tabular}{|c|c|c|c|c|c|c|}
\hline $\begin{array}{l}\text { Hot } \\
\text { spring }\end{array}$ & $\begin{array}{l}\text { Type of } \\
\text { sample }\end{array}$ & $\mathrm{pH}$ & $\begin{array}{c}\text { Temperature } \\
\left({ }^{\circ} \mathrm{C}\right)\end{array}$ & Sequencer & $\begin{array}{l}\text { Region } \\
\text { amplified }\end{array}$ & References \\
\hline Siloam, Limpopo, South Africa & Water & 9.5 & 63 & Roche 454 GS FLX & V4-V7 & Tekere et al., 2011 \\
\hline Lake Bogoria, Kenya & $\begin{array}{l}\text { Water, sediment and microbial } \\
\text { mat }\end{array}$ & $8.9-9.5$ & $40-80$ & Roche 454 GS FLX & V3-V4 & Dadheech et al., 2013 \\
\hline Arzakan and Jermuk, Armenia & Water and sediment & $7.20-7.50$ & $40-53$ & Roche 454 GS FLX & V4-V8 & Hedlund et al., 2013 \\
\hline $\begin{array}{l}\text { Bacon Manito Geothermal Field, } \\
\text { Philippines }\end{array}$ & Sediment & $3.72-6.58$ & 60-92 & Roche 454 GS FLX & V4-V8 & Huang et al., 2013 \\
\hline Furnas Valley, Saõ Miguel, Azores & $\begin{array}{l}\text { Water, sediment and microbial } \\
\text { mat }\end{array}$ & $2.5-8$ & $51-92$ & Roche 454 GS FLX & V2-V3 & Sahm et al., 2013 \\
\hline Yunnan province and Tibet, China & Sediment & $3.2-8.6$ & $47-96$ & Roche 454 GS FLX & V4 & Song et al., 2013 \\
\hline $\begin{array}{l}\text { Zavarzin, Uzon Caldera, } \\
\text { Kamchatka, Russia }\end{array}$ & Microbial mat & 6.6 & $56-58$ & Roche 454 GS FLX & V3 & Rozanov et al., 2014 \\
\hline Sungai Klah, Malaysia & Water and sediment & 8 & $75-85$ & Illumina MiSeq & V3-V4 & Chan et al., 2015 \\
\hline Jakrem, Meghalaya, India & Microbial mat & - & - & Illumina & V3 & Panda et al., 2015 \\
\hline Odisha, Deulajhari, India & Sediment & $7.14-7.83$ & $43-55$ & Illumina GAIIX & V3-V4 & Singh and Subudhi, 2016 \\
\hline
\end{tabular}

used this procedure to explore the methanogen diversity in Lake Pavin (Frech Massif Central), showing that this GC-independent procedure is less biased and can detect broader diversity than traditional amplicon sequencing. The same approach has been used to enhance the capture of functional genes coding for carbohydrate-active enzymes and proteases in agricultural soils (Manoharan et al., 2015), and could also be an interesting tool to study thermophilic populations.

Another method for targeted metagenomics enrichment is stable isotope probing (SIP) in which the environmental 
microorganisms are grown in the presence of substrates labeled with isotopes. As a consequence of metabolic activity, the isotope (usually ${ }^{13} \mathrm{C}$ or ${ }^{15} \mathrm{~N}$ ) is incorporated into the nucleic acids of the microbes metabolizing the substrate, increasing the density of DNA or RNA that can be after separated from unlabelled ones (Coyotzi et al., 2016). The high-density community DNA is then used as template to amplify by PCR the $16 \mathrm{~S}$ rRNA sequences (Brady et al., 2015) and/or some functional genes involved in the selected metabolic pathway, thus allowing the study of the microorganisms that are actively participating in the processes of interest. Gerbl et al. (2014) used this technique to assess the microbial populations implicated in the carbon cycle in the Franz Josef Quelle radioactive thermal spring (Austrian Central Alps).

Although the strategies of targeted metagenomics can be used to infer the taxonomic diversity of the community (16S rRNA gene profiling) or particular aspects of its functional diversity, a broader view of functional diversity, i.e., a more exhaustive answer to the question "what are they doing," is provided by shotgun metagenomics (Figure 1).

\section{Shotgun Metagenomics}

Random sequencing of metagenomic DNA using highthroughput sequencing technology is becoming increasingly common. In this approach, DNA is extracted from the whole community and subsequently sheared into small fragments that are independently sequenced. At present, this is considered the most accurate method for assessing the structure of an environmental microbial community, since it does not comprise any selection and reduces technical biases, especially the ones introduced by amplification of the 16S rRNA gene (Lewin et al., 2013). Shah et al. (2011) compared bacterial communities analyzed with both $16 \mathrm{~S}$ rRNA and whole shotgun metagenomics, revealing that the taxonomy derived from these two different approaches cannot be directly compared. This study also proposed that low abundance species are best identified through $16 \mathrm{~S}$ rRNA gene sequencing. Therefore, some high-temperature studies use, in parallel, both techniques to assess the taxonomic composition of the microbial community (Dadheech et al., 2013; Klatt et al., 2013; Chan et al., 2015).

The biodiversity of several hot environments such as oil reservoirs (Kotlar et al., 2011), compost (Martins et al., 2013), or hot springs (Zamora et al., 2015; Mehetre et al., 2016), was studied using shotgun metagenomics sequencing. Some of them are summarized in Table 2.

Development of NGS has greatly enhanced this approach. The most widely used platforms for this kind of analysis in high temperature environments are Illumina and Roche 454 (Table 2). Illumina currently offers the highest throughput per run and the lowest cost per-base (Liu et al., 2012), generating read lengths up to $300 \mathrm{bp}$. On the other hand, Roche 454 gives longer reads (1 $\mathrm{kb}$ maximum), which are easier to map to a reference genome; however it is more expensive and has lower throughput (van Dijk et al., 2014). Even though they have substantial differences (Kumar et al., 2015), some studies have demonstrated that the information recovered from both sequencing platforms is comparable when analyzing the biodiversity of the same sample (Luo et al., 2012).
The main limitations of shotgun metagenome sequencing include its relatively expensive setup cost and the requirement of very high computing power for data storage, retrieval, and analysis. Another important drawback of this approach is that high quality whole community DNA is needed, which makes the extraction a critical step in the process of generating metagenomic data. Therefore, some studies have focused on the improvement of metagenomic DNA extraction from thermal environments (Mitchell and Takacs-Vesbach, 2008; Li et al., 2013a; Gupta et al., 2016). Nowadays the NGS platforms allow sequencing with low inputs of DNA, nevertheless in some cases it is necessary to amplify the metagenomic DNA to obtain enough quantity for preparing the sequencing libraries. As an example, Nakai et al. (2011) used multiple displacement amplification with Phi29 to sequence the metagenome of the hydrothermal fluid of the Mariana Trough, an active back-arc basin in the western Pacific Ocean. This amplification step is frequently required to generate viral metagenomic libraries, introducing a subsequent bias (Kim and Bae, 2011), as the extraction of enough high quality viral nucleic acids is a difficult process that usually relies on virus concentration methods.

To assess the taxonomic diversity with the short metagenomic reads obtained after sequencing, there are several non-exclusive approximations that can be done: analyzing taxonomically informative marker genes, grouping sequences into defined taxonomic groups (binning) or/and assembling sequences into definite genomes (Sharpton, 2014).

As mentioned before, the most frequently used taxonomically informative marker genes are rRNA genes or protein-coding genes that tend to be single copy and common to microbial genomes. In this approach, those reads that are homologs to the marker gene are identified in the sequences of the metagenome and annotated using sequence or phylogenetic similarity to the marker gene database sequences. Bioinformatics applications for this purpose include MetaPhyler (Liu et al., 2010), EMIRGE (Miller et al., 2011), and AMPHORA (Wu and Scott, 2012). Gladden et al. (2011) used EMIRGE to reconstruct near fulllength small subunit (SSU) rRNA genes from metagenomic Illumina sequences to determine the taxonomy of compostderived microbial consortia adapted to switchgrass at $60^{\circ} \mathrm{C}$, finding a low-diversity community with predominance of Rhodothermus marinus and Thermus thermophilus. In another study, Klatt et al. (2011) used AMPHORA to identify the phylogenetic and functional marker genes in the assemblies of several hot springs cyanobacterial metagenomes from YNP. These studies allowed the discovery of novel chlorophototrophic bacteria belonging to uncharacterized lineages within the order Chlorobiales and within the Kingdom Chloroflexi. In a similar approach, Lin et al. (2015) and Colman et al. (2016) used a 16S rRNA gene-based diversity method blasting the metagenomic reads against the SILVA reference database to characterize bacterial populations in Shi-Huang-Ping acidic hot spring (Taiwan) and in two thermal springs in YNP, respectively.

Taxonomic binning is defined as the process of grouping reads or contigs and assigning them to operational taxonomic units, depending on information such as sequence similarity, sequence composition or read coverage (Dröge and McHardy, 
TABLE 2 | Examples of high temperature environments studied with shotgun metagenomics.

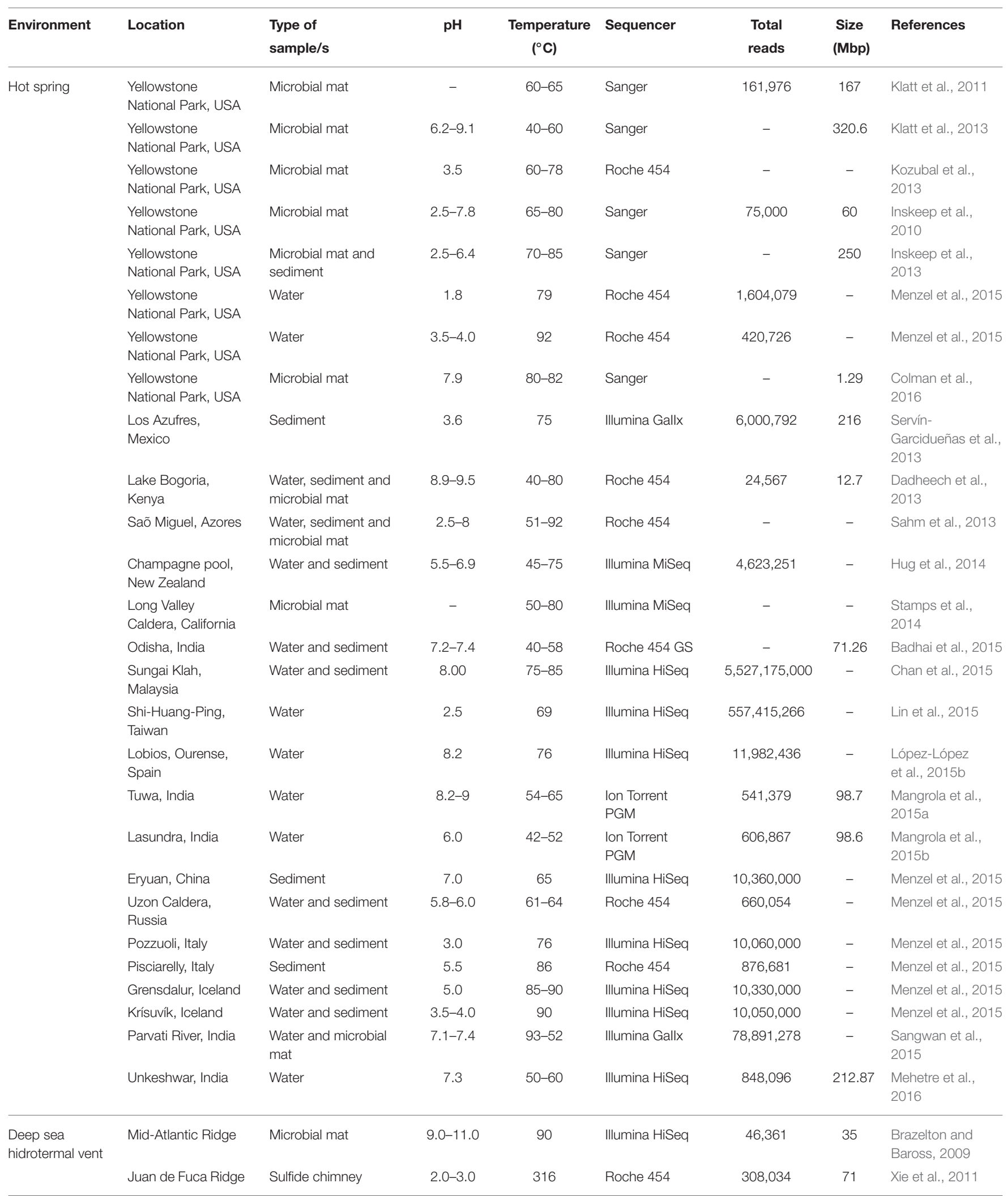


TABLE 2 | Continued

\begin{tabular}{|c|c|c|c|c|c|c|c|c|}
\hline Environment & Location & $\begin{array}{l}\text { Type of } \\
\text { sample/s }\end{array}$ & $\mathrm{pH}$ & $\begin{array}{l}\text { Temperature } \\
\left({ }^{\circ} \mathrm{C}\right)\end{array}$ & Sequencer & $\begin{array}{l}\text { Total } \\
\text { reads }\end{array}$ & $\begin{array}{l}\text { Size } \\
\text { (Mbp) }\end{array}$ & References \\
\hline & $\begin{array}{l}\text { Guaymas Baisin, } \\
\text { Gulf of California }\end{array}$ & $\begin{array}{l}\text { Black-smoker } \\
\text { chimney }\end{array}$ & 6.0 & 190 & Roche 454 & 512,83 & 196.38 & He et al., 2013 \\
\hline & Juan de Fuca Ridge & Vent fluid & - & 125 & Roche 454 & 808,051 & - & $\begin{array}{l}\text { Anderson et al., } \\
2014\end{array}$ \\
\hline \multirow[t]{3}{*}{ Biogas reactor } & Germany & Microbial mat & $6.64-8.11$ & 55 & Roche 454 & 303,493 & 120.50 & $\begin{array}{l}\text { Rademacher et al., } \\
2012\end{array}$ \\
\hline & Linköping, Sweden & Digester material & $7.5-8.1$ & $50-55$ & Roche 454 & 250,478 & - & $\begin{array}{l}\text { Sundberg et al., } \\
2013\end{array}$ \\
\hline & Romania & Sludge & $6.94-7.62$ & 55 & $\begin{array}{l}\text { Ion Torrent } \\
\text { PGM }\end{array}$ & 300,000 & - & Pap et al., 2015 \\
\hline \multirow[t]{2}{*}{ Oil reservoir } & Norwegian sea & Oil, water and gas & - & 85 & Roche 454 & 702,607 & 345 & Kotlar et al., 2011 \\
\hline & $\begin{array}{l}\text { Gippsland Basin, } \\
\text { Australia }\end{array}$ & Formation water & 7.2 & 120 & Roche 454 & - & - & Li et al., 2013a \\
\hline Compost & $\begin{array}{l}\text { São Paulo Zoo } \\
\text { Park, Brazil }\end{array}$ & Compost material & 7 & $65.8-67.2$ & Roche 454 & $3,167,044$ & 836 & $\begin{array}{l}\text { Martins et al., } \\
2013\end{array}$ \\
\hline Gold mine & South Africa & Fracture water & 9.3 & 60 & $\begin{array}{l}\text { Sanger and } \\
\text { Roche } 454\end{array}$ & 500,008 & - & $\begin{array}{l}\text { Chivian et al., } \\
2008\end{array}$ \\
\hline
\end{tabular}

In those studies comprising several samples, the total reads and size reflected is just the one of the sample with higher values.

2012). Metagenomic sequences can be binned based on their sequence similarity to a database of taxonomically annotated sequences using tools like MEGAN (Huson et al., 2011) or MGRAST, a public resource for the automatic phylogenetic and functional analysis of metagenomes (Meyer et al., 2008). MEGAN bases its taxonomic classification on the NCBI taxonomy using BLAST. With this tool, Klatt et al. (2013) assessed the community structure of six phototrophic microbial mat communities in YNP and Badhai et al. (2015) revealed the dominance of Bacteria over Archaea in four geothermal springs in Odisha, India. Taxonomic binning can be done with assembled or unassembled reads, although assessing taxonomic abundance with assembled data can led to a miscalculation of the abundance of some taxa, as contigs are treated as a single sequence in most downstream analysis, hindering the analytical tools to accurately quantify the abundance of the taxon (Sharpton, 2014).

Assembly is described as the process of merging individual metagenomic reads into longer pieces of contiguous sequences (contigs) based on overlapping sequences and paired read information (Dröge and McHardy, 2012). Bioinformatic implements like MetaVelvet (Namiki et al., 2012) or IDBAUD (Peng et al., 2012) have been used in the assembly of whole shotgun metagenome reads to study the taxonomical composition of different high-temperature environments. For example, MetaVelvet was applied in the study of eight globally distributed hot springs by Menzel et al. (2015) and IDBA-UD in the analysis of the community composition of Sungai Klah hot spring in Malaysia (Chan et al., 2015). This step can simplify bioinformatic analysis, but it may also produce chimeras, therefore researchers often bin reads and assemble each bin independently to decrease the probability of generating chimeras (Sharpton, 2014).

In recent studies, the integration of assembly and taxonomic binning by sequence composition allowed the reconstruction of several partial genomes from high-temperature environments such as the genome of a novel archaeal Rudivirus obtained from a Mexican hot spring, (Servín-Garcidueñas et al., 2013) or the draft genome sequence of Thermoanaerobacter sp. strain A7A, reconstructed from the metagenome of a $102^{\circ} \mathrm{C}$ hydrocarbon reservoir in the Bass Strait, Australia (Li et al., 2013b). Using a similar approach, Sangwan et al. (2015), reconstructed the genome of the bacterial predator Bdellovibrio ArHS, with the metagenomic assembly of the microbial mats of an arsenic rich hot spring in the Parvati river valley (Manikaran, India). Also, Sharma et al. (2016) combining genomic and metagenomic data, used two Cellulosimicrobium cellulans genomes derived from metagenomics, to study the evolution of pathogenicity across the species of C. cellulans.

\section{FUNCTIONAL ANALYSIS OF THERMOPHILES}

\section{Sequence-Based Function Prediction}

The metagenomic reads obtained from shotgun sequencing of an environmental DNA can be annotated with functions to determine the functional diversity of the microbial community. This usually comprises two steps: identifying metagenomic reads that contain protein coding sequences (gene prediction), and comparing the coding sequences to a database of genes, proteins, protein families, or metabolic pathways (gene annotation) (Sharpton, 2014). Some frequently used databases for functional 
annotation are the SEED annotation system (Overbeek et al., 2014), the KEGG orthology (KO) database (Kanehisa et al., 2016) or the Pfam database, based on hidden Markov models (HMM) to classify in accordance with the protein domains (Finn et al., 2015). There are several robust web resources that can be easily used to perform gene prediction, database search, family classification, and annotation, including MGRAST (Meyer et al., 2008), IMG/M (Markowitz et al., 2014), or SUPER-FOCUS (Silva et al., 2015). Considerable functional profiles of thermophilic populations have been based on these tools such as the study of the microbiota of Tuwa hot spring in India (Mangrola et al., 2015a) in which the functional annotation was performed using the MG-RAST pipeline. In this study, a high number of annotated features were classified as unknown function, suggesting the potential source of novel microbial species and their products. Similar results were found in the metagenome of Unkeshwar, another hot spring in India, where pathway annotation was done using KEGG (Mehetre et al., 2016). For each contig sequence, the assignment of $\mathrm{KO}$ numbers obtained from known reference hits was done, revealing up to $20 \%$ unclassified sequences. These results reflect a promising world of undiscovered proteins that could be explored to find new catalysts for biotechnological applications.

In this approach, it is important to consider that, despite the information given by functional annotation of the metagenomic sequences; the presence of a gene on a metagenome does not mean that it is expressed. Therefore, functional metagenomics, metatranscriptomics, and metaproteomics assays are necessary to assess the real community functional activity. To increase the probability of finding active functional genes involved in a substrate uptake and transformation, some studies use a substrate-induced enrichment of the community before the metagenomic DNA extraction. After, these genes can be detected either by sequence (Graham et al., 2011; Wang et al., 2016) or by functional metagenomics (Chow et al., 2012). Using this procedure, Graham et al. (2011) found and characterized an hyperthermophilic cellulase in an archaeal community, obtained by growth at $90^{\circ} \mathrm{C}$ of the sediment of a geothermal source enriched with crystalline cellulose.

Another important limitation of shotgun metagenomics is that the databases may be subjected to phylogenetic biases, as some communities are more accurately or more exhaustively annotated than others (Chistoserdova, 2010).

\section{Functional Metagenomics}

Function-based metagenomics relies on the construction of metagenomic libraries by cloning environmental DNA into expression vectors and propagating them in the appropriate hosts, followed by activity-based screening. After an active clone is identified, the sequence of the clone is determined, the gene of interest is amplified and cloned with the subsequent expression and characterization of the product to explore its biotechnological potential (Figure 2). This technique has the advantage of not requiring the cultivation of the native microorganisms or previous sequence information of known genes, thus representing a valuable approach for mining enzymes with new features.

The use of functional metagenomics allows the discovery of novel enzymes whose functions would not be predicted based on DNA sequence. This approach complements sequencebased metagenomics as the information from function-based analyses can be used to annotate genomes and metagenomes derived exclusively from sequence-based analyses (Lam et al., 2015). Therefore, several investigations in thermal environments combine sequencing methods (taxonomical and functional characterization) with functional screening of clones (Chen et al., 2007; Wemheuer et al., 2013; Leis et al., 2015; López-López et al., 2015b).

Depending on the size of the insert, functional metagenomics can be explored using fosmids (35-45 kb insert), BACs $(\sim 200$ $\mathrm{kb}$ insert), cosmids (30-42 kb insert), or plasmids $(<10 \mathrm{~kb}$ insert). Bigger inserts are more likely to contain complete genes and operons, allowing the expression of more enzymes. A great number of high temperature functional metagenomics studies use the commercial vector pCC1FOS (Table 3), which allows inserts up to $40 \mathrm{~kb}$, and it is available in a toolkit to simplify the library construction. More information about this vector is compiled in Lam et al. (2015) review.

There are several technically challenging steps in library construction. Mainly, the high quality and length of the metagenomic DNA required for proceeding to the ligation into the vector and the need of obtaining a high proportion of clones in order to cover all the variability of the microbial community. This limitation is particularly important in soil studies, where it has been reported that contaminants like humic acids are present in metagenomic DNA extracts, interfering with the subsequent enzymatic reactions. Therefore, the widely extended method of soil DNA extraction established by Zhou et al. (1996), is usually accomplished with further purification of the sample that can lead to a loss of DNA yield. Some studies show that the humic acids can be easily removed by gel electrophoresis of the metagenomic DNA followed by gel extraction, as humic acids migrate faster than the large metagenomic DNA (Kwon et al., 2010). This simple approach was used to construct a Turpan Basin soil metagenomic library for a functional screening of thermostable beta-galactosidases (Wang et al., 2014). Alternatively, to avoid contaminating the circulating buffer, electrophoresis can be paused after humic acids have formed a front, excising the part of the gel containing the humic acids, and replacing it with fresh gel (Cheng et al., 2014).

Another important drawback that compromises the functional metagenomics approach is the selection of the expression host. Although the commonly used E. coli strains have relaxed requirements for promoter recognition and translation initiation, some genes from environmental samples may not be efficiently expressed due to differences in codon usage, transcription and/or translation initiation signals, protein-folding elements, post-translational modifications, or toxicity of the active enzyme (Uchiyama and Miyazaki, 2009). This problem could be even worse when the proteins expressed need special conditions to be active, such as high temperatures, considering that mesophiles, like E. coli, do not 


\section{Sequence-based screening}

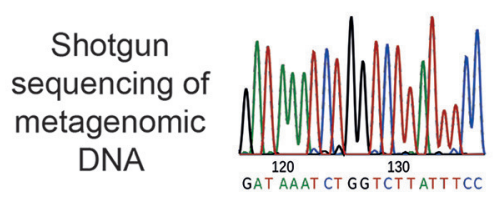

Gene prediction<smiles>[CH]1C=C1</smiles>

Gene annotation<smiles>C1CCCCC1</smiles>

Primer design and amplification

\section{Function-based screening}
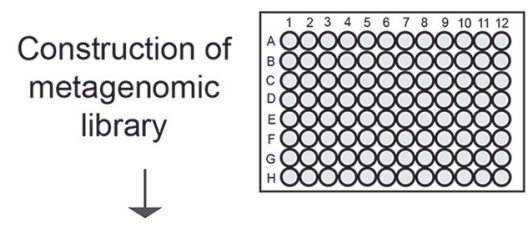

Activity detection

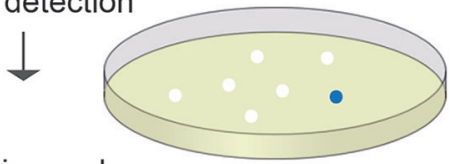

Isolation and sequencing of positive clones

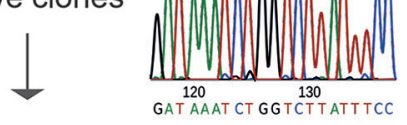

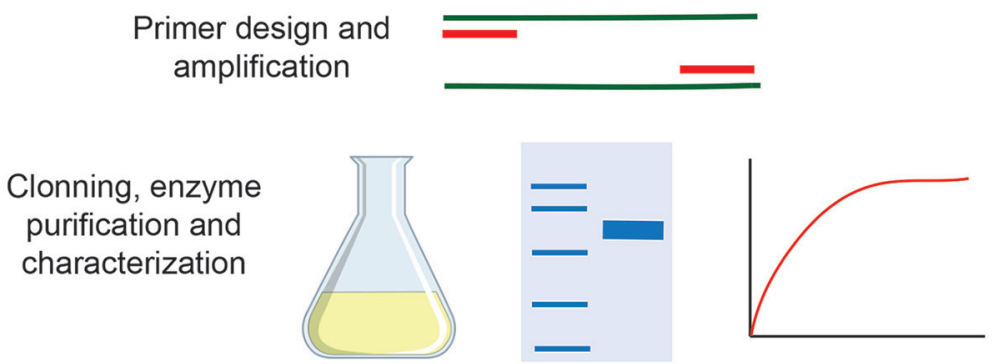

FIGURE 2 | The two major strategies used for screening metagenomes in search of new thermozymes.

survive at these high temperature conditions. Accordingly, an alternative expression host may be required to overcome the heterologous expression of some genes derived from hot environments and thus, identify a broader range of enzymes. The thermophilic bacterium $T$. thermophilus has been proposed as a good candidate for function-based detection of thermozymes. In a recent functional screening to detect esterases, Leis et al. (2015) constructed two large insert fosmid metagenomic libraries of compost and hot spring water using pCT3FK, a pCC1FOS derived T. thermophilus/E. coli shuttle fosmid (Angelov et al., 2009), in T. thermophilus and compared them to the same libraries expressed in E. coli. Only two esterases were found at $60^{\circ} \mathrm{C}$ in the libraries generated in $E$. coli while 5 different esterases were discovered in the same libraries expressed in T. thermophilus. Therefore, this could be a suitable system to improve the detection of metagenome-derived thermozymes. The main restriction of this approach is that pCT3FK integrates into T. thermophilus chromosomal DNA. In fact, the genomes of the positive clones isolated by Leis et al. (2015) were completely sequenced before proceeding with the PCR amplification and cloning of the candidate genes, with the consequent cost of time and money. Other versatile broad-host-range cosmids that have been used in a soil study (pJC8 and pJC24) allow the phenotypic screening of the library in bacteria such as Bacillus and in the yeast Saccharomyces (Cheng et al., 2014). The selection of the appropriate substrate for the functional screening is also a crucial step in this approach, as the substrate may cause biases in the selection of the activities of interest. Recent studies suggest that the initial selection of active clones with general substrates should be followed by a more specific one to improve the effectiveness of the detection (Ferrer et al., 2016). Other biases and limitations of functional metagenomics and strategies for its improvement have been previously reviewed by Ferrer et al. (2005) and Ekkers et al. (2012).

Some hot environments where function-based screening of microbial communities have been done include hot springs (López-López et al., 2015b), deserts (Neveu et al., 2011), petroleum reservoirs (de Vasconcellos et al., 2010), or humanmade environments like a biogas plant (Ilmberger et al., 2012), demonstrating the potential of functional metagenomics as a very important source of new thermozymes.

\section{METAGENOME-DERIVED THERMOZYMES}

Many industrial processes require elevated temperatures to take place. Thus, microorganisms surviving at temperatures above $55^{\circ} \mathrm{C}$ represent an important source of biotechnological richness for high temperature bioprocesses by producing a large variety 
TABLE 3 | Examples of thermozymes obtained by functional metagenomics.

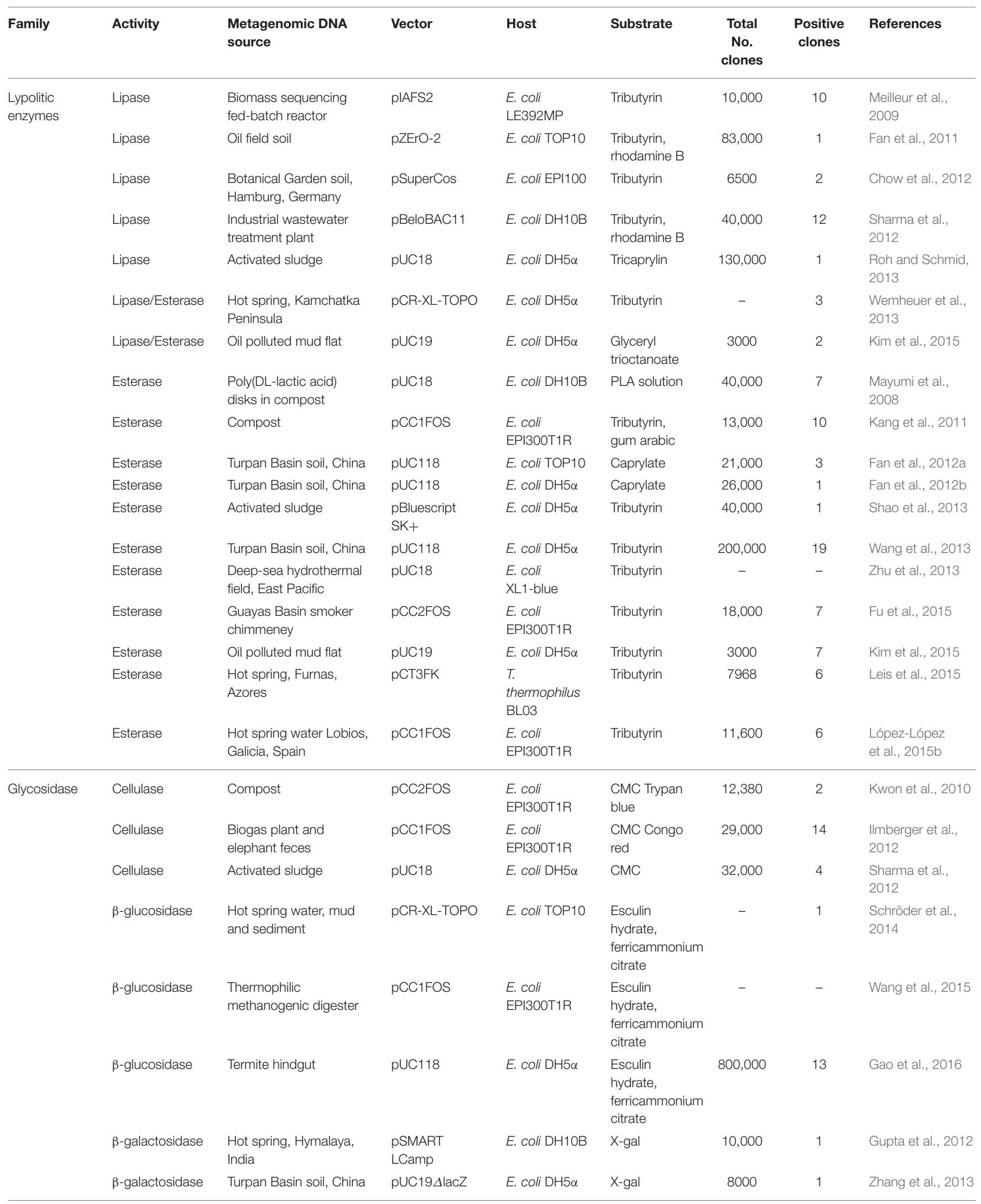


TABLE 3 | Continued

\begin{tabular}{|c|c|c|c|c|c|c|c|c|}
\hline Family & Activity & $\begin{array}{l}\text { Metagenomic DNA } \\
\text { source }\end{array}$ & Vector & Host & Substrate & $\begin{array}{l}\text { Total } \\
\text { No. } \\
\text { clones }\end{array}$ & $\begin{array}{l}\text { Positive } \\
\text { clones }\end{array}$ & References \\
\hline & $\beta$-galactosidase & Turpan Basin soil, China & pUC19 $19 \mathrm{lacZ}$ & E. coli DH5 $\alpha$ & X-gal & 700,000 & 1 & Wang et al., 2014 \\
\hline & Xylanase & Compost & pCC2FOS & $\begin{array}{l}\text { E. coli } \\
\text { EPI300T1R }\end{array}$ & Xylan & 12,380 & 5 & Kwon et al., 2010 \\
\hline & Endoxylanase & Compost-soil & p18 GFP & E. coli DH10B & RBB-xylan & 180,000 & 1 & Verma et al., 2013 \\
\hline & $\beta$-xylosidase & $\begin{array}{l}\text { Thermophilic } \\
\text { methanogenic digester }\end{array}$ & pCC1FOS & $\begin{array}{l}\text { E. coli } \\
\text { EPI300T1R }\end{array}$ & $\begin{array}{l}\text { Esculin } \\
\text { hydrate, } \\
\text { ferricammonium } \\
\text { citrate }\end{array}$ & - & - & Wang et al., 2015 \\
\hline & Various & $\begin{array}{l}\text { Raw and torrified wheat } \\
\text { straw }\end{array}$ & pCC1FOS & $\begin{array}{l}\text { E. coli } \\
\text { EPI300T1R }\end{array}$ & $\begin{array}{l}\text { X-fuc, X-gal, } \\
\text { X-Xyl, X-Man, } \\
\text { X-cel, X-glu }\end{array}$ & 44,000 & 71 & $\begin{array}{l}\text { Maruthamuthu } \\
\text { et al., } 2016\end{array}$ \\
\hline \multirow[t]{2}{*}{ Amylase } & $\alpha$-amylase & Western Ghats soil & pCC1FOS & $\begin{array}{l}\text { E. coli } \\
\text { EPI300T1R }\end{array}$ & $\begin{array}{l}\text { Potassium } \\
\text { iodide } \\
\text { solution }\end{array}$ & 76,000 & 1 & Vidya et al., 2011 \\
\hline & $\alpha$-amylase & Biogas reactor & pBK-CMV & E. coli XLOLR & $\begin{array}{l}\text { AZCL- } \\
\text { amylose }\end{array}$ & 2000 & 1 & $\begin{array}{l}\text { Jabbour et al., } \\
2013\end{array}$ \\
\hline Phosphatase & Phytase & Soil & pCC1FOS & $\begin{array}{l}\text { E. coli } \\
\text { EPI300T1R }\end{array}$ & Phytate & 14,000 & 28 & Tan et al., 2014 \\
\hline \multirow[t]{5}{*}{ Protease } & Serine protease & Sand Gobi desert & pCC1FOS & $\begin{array}{l}\text { E. coli } \\
\text { EPI300T1R }\end{array}$ & Skim milk & 17,000 & 16 & Neveu et al., 2011 \\
\hline & Serine protease & $\begin{array}{l}\text { Sand Death Valley } \\
\text { desert }\end{array}$ & pBSKII+ & E. coli DH10B & Skim milk & 30,000 & 1 & Neveu et al., 2011 \\
\hline & Serine protease & Soil & pHT01 & E. coli DH10B & AZCL-casein & - & 1 & Biver et al., 2013 \\
\hline & $\begin{array}{l}\text { Patatin-like } \\
\text { protein }\end{array}$ & Hot spring, Kamchatka & pCR-XL-TOPO & E. coli $\mathrm{DH} 5 \alpha$ & Skim milk & - & 1 & $\begin{array}{l}\text { Wemheuer et al., } \\
2013\end{array}$ \\
\hline & Serine protease & $\begin{array}{l}\text { Hot spring, } \\
\text { Chumathang Ladakh }\end{array}$ & pUC18 & E. coli $\mathrm{DH} 5 \alpha$ & Casein & 9000 & 1 & Singh et al., 2015 \\
\hline \multirow[t]{3}{*}{ Oxidoreductase } & $\begin{array}{l}\text { Extradiol } \\
\text { dioxygenase }\end{array}$ & Activated sludge & pCC1FOS & $\begin{array}{l}\text { E. coli } \\
\text { EPI300T1R }\end{array}$ & Catechol & 96,000 & 91 & $\begin{array}{l}\text { Suenaga et al., } \\
2007\end{array}$ \\
\hline & & Oil reservoir & pCC2FOS & $\begin{array}{l}\text { E. coli } \\
\text { EPI300T1R }\end{array}$ & Hexadecane & 5000 & 72 & $\begin{array}{l}\text { de Vasconcellos } \\
\text { et al., } 2010\end{array}$ \\
\hline & Dioxygenase & Activated sludge & pBeloBAC11 & E. coli $\mathrm{DH} 10 \mathrm{~B}$ & $\begin{array}{l}\text { Phenol, } \\
\text { catechol }\end{array}$ & 40,000 & 4 & $\begin{array}{l}\text { Sharma et al., } \\
2012\end{array}$ \\
\hline
\end{tabular}

of biocatalysts. Biotechnological processes carried out at high temperatures provide numerous benefits such as higher solubility of reagents, and reduced risk of microbial contamination (Mirete et al., 2016). From an industrial point of view, thermozymes possess certain advantages over their mesophilic counterparts as they are active and efficient under high temperatures, extreme $\mathrm{pH}$ values, high substrate concentrations, and high pressure (Sarmiento et al., 2015). Some of them are also highly resistant to denaturing agents and organic solvents (Fan et al., 2011; Roh and Schmid, 2013). In addition, thermozymes are easier to separate from heat-labile proteins during purification steps as reported by Pessela et al. (2004). As a result, high temperatureactive enzymes can be potentially used in diverse industrial and biotechnological applications including food, paper and textile processing, chemical synthesis and the production of pharmaceuticals.
Some thermostable enzymes are still recovered by isolation from thermophilic microorganisms (Shi et al., 2013; Fuciños et al., 2014; Sen et al., 2016), however metagenomics has opened a new important field in the discovery of novel biocatalysts and has been revealed as a promising mining strategy of resources for the biotechnological and pharmaceutical industry. There are two different ways of screening a metagenome in search of thermozymes: a sequence-based approach and a function-based approach (Figure 2).

Sequence-based screening methods rely on the prior knowledge of conserved sequences of domains/proteins/families of interest. It involves primer designing followed by amplification and cloning of the metagenomic genes. The main drawback of this approach is its failure to detect fundamentally different novel genes, as it cannot discover non-homologous enzymes. Some potential biocatalysts have been isolated mining metagenomic 
TABLE 4 | Examples of thermozymes isolated by sequence-based screening of metagenomes.

\begin{tabular}{|c|c|c|}
\hline Enzyme & Source of metagenomic DNA & References \\
\hline Cellulase & Long-term dry thermophilic methanogenic digester & Wang et al., 2015 \\
\hline Xylanase & Cow dung compost & Sun et al., 2015 \\
\hline Endoxylanase & Compost & Dougherty et al., 2012 \\
\hline$\beta$-galactosidase & Hot spring water, Yongtai & Liu et al., 2015 \\
\hline Pectinase & Hot spring soil, Manikaran, India & Singh et al., 2012 \\
\hline$\alpha$-fucosidase & Compost & Dougherty et al., 2012 \\
\hline Phytase (phosphatase) & Insect-cultivated fungus gardens & Tan et al., 2016 \\
\hline Limonene 1,2-epoxide hydrolase & Hot springs water & Ferrandi et al., 2015 \\
\hline Nitrilase & Atlantis II Deep Brine Pool, Red Sea & Sonbol et al., 2016 \\
\hline
\end{tabular}

sequences in prospecting for genes coding thermozymes (Table 4). Namely, a gene encoding a thermostable pectinase was isolated from a soil metagenome sample collected from hot springs of Manikaran (India), using a PCR-based cloning strategy with primers designed based on known sequences of pectinase genes from other species (Singh et al., 2012). The recombinant protein is proposed to be of great use in industrial processes due to its activity over a broad $\mathrm{pH}$ range. Thanks to this search based on sequence homology to related gene families, 22 putative ORFs (open reading frames) were identified from a switchgrass-adapted compost community finding a bi-functional $\beta$-xylosidase $/ \alpha$ arabinofuranosidase that maintained $\sim 75 \%$ of its activity after $16 \mathrm{~h}$ at $60^{\circ} \mathrm{C}$ (Dougherty et al., 2012). The same sequencebased approach was used by Ferrandi et al. (2015) who discovered, cloned and characterized two novel limonene1,2-epoxide hydrolases (LEHs) with an in-silico screening of the LEHs sequences in the assembled contigs from hot spring metagenomes.

The function-based metagenomic screening is the most important way to discover novel thermozymes as it doesn't rely on the sequence. The main advantage of directly screening for enzymatic activities from metagenome libraries is that it gives access to previously unknown genes and their encoded enzymes. Thus, some completely new thermozymes that couldn't be found by sequence screening have been discovered, like the unusual glycosyltransferaselike enzyme with $\beta$-galactosidase activity recovered by Wang et al. (2013) from a Turpan Basin soil metagenomic library. Function-based metagenomic screening has allowed the discovery of a wide range of thermozymes (Table 3). In this review, we focus on the recovery of the functional-derived thermostable metagenomic enzymes that are mostly used in biocatalysis and industrial sectors, such as lipolytic enzymes, glycosidases, proteases, and oxidoreductases (Böhnke and Perner, 2015).

\section{Lipolytic Enzymes}

Lipolytic enzymes, comprising esterases (EC 3.1.1.1) and lipases (EC 3.1.1.3), are extensively distributed in microorganisms, plants, and animals. They catalyze the hydrolysis, synthesis, or transesterification of ester bonds. At present, these enzymes represent about $20 \%$ of commercialized enzymes for industrial use (López-López et al., 2015a), as they have great potential in several industrial processes such as production of biodegradable polymers, detergents, food flavoring, oil biodegradation, or waste treatment, among others (Anobom et al., 2014). Therefore, a considerable number of functional metagenomics studies are focused on mining thermal environments in search for these enzymes (Table 3).

Lipases are generally defined as carboxylesterases hydrolyzing water-insoluble (acyl chain length $>10$ ) triglycerides, with trioleoylglycerol as the standard substrate. In contrast, esterases catalyze the hydrolysis of short-chain esters (acyl chain length $<10$ ) with tributylglycerols (tributyrin) as the standard substrate, although lipases are also capable of hydrolyzing esterase substrates (Rhee et al., 2005). At least 200 different substrates have been successfully applied in assays for functional selection of esterase/lipase biocatalysts in metagenomic clone libraries (Ferrer et al., 2016), including the widely used tributyrin (Rhee et al., 2005; Meilleur et al., 2009; López-López et al., 2015b), and p-nitrophenyl (NP) acetate (Wang et al., 2013). Meilleur et al. (2009) isolated a new alkali-thermostable lipase with an optimal activity at $60^{\circ} \mathrm{C}$ and $\mathrm{pH} 10.5$ by functional screening of a metagenomic cosmid library from the biomass produced in a gelatin enriched fed-batch reactor. Another gene coding for a thermostable esterase was detected by functional screening of fosmid environmental DNA libraries constructed with metagenomes from thermal environmental samples of Indonesia (Rhee et al., 2005). The recombinant esterase was active from 30 up to $95^{\circ} \mathrm{C}$ with an optimal $\mathrm{pH}$ of approximately 6.0. Mayumi et al. (2008), generated a metagenomic library with the community DNA extracted from biodegradable polyester 
poly(lactic acid) (PLA) disks buried in compost and found a PLA depolymerase that had an esterase domain. Purified enzyme showed the highest activity at $70^{\circ} \mathrm{C}$ and degraded not only PLA, but also various aliphatic polyesters, tributyrin, and p-NP esters. As mentioned before, those enzymes able of retaining activity even in the presence of organic solvents are considered very interesting for industrial applications. A new thermophilic organic solvent-tolerant and halotolerant esterase with an optimum $\mathrm{pH}$ and temperature of 7.0 and $50^{\circ} \mathrm{C}$, respectively, was found in the functional screening of a soil metagenomic library with 48,000 clones (Wang et al., 2013).

Apart from these above cited sources, metagenomic esterases, and lipases have been isolated by functional screening of other hot environments like deep-sea hydrothermal vents (Zhu et al., 2013) and hot springs (López-López et al., 2015b) as shown in Table 3. A more extensive review of metagenome derived extremophilic lipolytic enzymes can be found in López-López et al. (2014).

\section{Glycosidases}

The enzymes that hydrolyze glycosidic bonds between two or more sugars or a sugar and a nonsugar moiety within carbohydrates or oligosaccharides are known as glycosyl hydrolases (GHs) or glycosidases (Sathya and Khan, 2014). There are 115 GH families, collected in the Carbohydrate Active enZyme database (CAZy; http://www.cazy.org) (Lombard et al., 2014), including a broad number of enzymes like cellulases, $\beta$-galactosidases, amylases, and pectinases.

Cellulases encompass a group of complex enzymes conformed by endo- $\beta-1,4$ glucanases, cellobiohydrolases, cellodextrinases, and $\beta$-glucosidases. These enzymes work together to degrade cellulose into simple sugars and their thermostable representatives could be used in biofuel production from lignocellulosic biomass (Bhalla et al., 2013). Several substrates can be employed in plate-based screens for the functional detection of clones harboring cellulase activity, such as carboxymethyl-cellulose in combination with trypan blue, Gram's iodine, or Congo Red. Meddeb-Mouelhi et al. (2014), found that Gram's iodine may lead to the identification of false positives, making Congo Red a more suitable dye for this approach. Using Congo Red dye as a colorimetric substrate, Ilmberger et al. (2012) obtained two fosmid clones derived from a carboxymethyl-cellulose (CMC)-enriched library from a biogas plant. These two fosmids were designated as pFosCelA2 and pFosCelA3, encoding two thermostable cellulases with significant activities in the presence of $30 \%(\mathrm{v} / \mathrm{v})$ ionic liquids (ILs). This is an interesting property for the cellulose degradation, as cellulose could increase its solubility in the ILs.

From the group of cellulases, $\beta$-glucosidases have attracted considerable attention in recent years due to their important roles in various biotechnological processes such as hydrolysis of isoflavone glucosides or the production of fuel ethanol from agricultural residues (Singhania et al., 2013). Other uses of $\beta$-glucosidases include the cleavage of phenolic and phytoestrogen glucosides from fruits and vegetables for medical applications or to enhance the quality of beverages. An archaeal $\beta$-glucosidase (Bgl1) showing activity toward cellobiose, cellotriose, and lactose was isolated from a metagenome from a hydrothermal spring in the island of S $\gamma_{0}$ Miguel (Azores, Portugal) (Schröder et al., 2014).

$\beta$-Galactosidases (EC 3.2.1.23), which hydrolyze lactose to glucose and galactose, have two main applications in the food industry: the production of low-lactose milk and dairy products for lactose intolerant people and the generation of galactooligosaccharides from lactose by the transgalactosylation reaction. These enzymes can be also used in the revalorisation of cheese whey (Becerra et al., 2015), a by-product of the dairy industry with a high organic load that can be considered a pollutant.

The most widely used substrate for the $\beta$-galactosidase screening, 5 -bromo-4-chloro-3-indolyl- $\beta$-D-galactopyranoside (X-gal), is the substrate providing, in some cases, the lowest number of positive hits in relation to the total number of clones screened (Ferrer et al., 2016). Usually, the positive clones capable of hydrolyzing the X-gal are further tested against ortho-NP- $\beta$ galactoside (ONPG) and lactose (Wierzbicka-Woś et al., 2013). Mayor drawbacks for the use of $\beta$-galactosidase in industrial processes is the inhibition by the reaction products, leading to a decrease in the reaction rates or even to stop the enzymatic reaction completely. The thermostable $\beta$-galactosidase (Gal308) discovered by Zhang et al. (2013) exhibited high tolerance to galactose and glucose with the highest activity at $78^{\circ} \mathrm{C}$, an optimum $\mathrm{pH}$ of 6.8 and high enzyme activity with lactose as substrate. The authors suggest that these properties would make it a good candidate for the production of low-lactose milk and dairy products. Another novel and thermostable alkalophilic $\beta$-D-galactosidase with an optimum temperature at $65^{\circ} \mathrm{C}$ and with high transglycosylation activity was identified through functional screening of a metagenomic library from a hot spring in northern Himalayan region of India (Gupta et al., 2012).

Xylans, made of $\beta-1,4$ linked xylopyranoses as a linear backbone with branches, constitute the second most significant group of polysaccharides in plant cell walls and are degraded by xylanases (Sathya and Khan, 2014). These hemicellulolytic enzymes are mostly used as biobleaching agents in the paper and pulp industry. The discovery of thermostable and alkali-stable xylanases has become an important goal in this field since this process requires high temperatures and alkali media, but this is not the only application of thermostable xylanases (Kumar et al., 2016). Functional metagenomics of hot environments represents an interesting source of xylanases. As an example, a novel alkali-stable and thermostable GH-11 endoxylanase encoding gene $(M x y l)$, was isolated by functional screening of a compostsoil metagenome (Verma et al., 2013). The thermostability of this enzyme was subsequently engineered by directed site mutagenesis (Verma and Satyanarayana, 2013).

Amylases are known as enzymes that catalyze the hydrolysis of starch into sugars (Sundarram et al., 2014). A novel and thermostable amylase with the highest activity at $90^{\circ} \mathrm{C}$ was retrieved from a black smoker chimney by combining fosmid library construction with pyrosequencing (Wang et al., 2011). Another $\alpha$-amylase was isolated in the functional screening of a metagenomic library of Western Ghats soil constructed in pCC1FOS. This amylase retained 30\% activity after incubation 
for $60 \mathrm{~min}$ at $80^{\circ} \mathrm{C}$ and had an optimal $\mathrm{pH}$ of 5.0 and could be potentially used in some industrial processes like liquefaction and saccharification of starch in food industry, or formulation of enzymatic detergents and removing starch from textiles (Vidya et al., 2011).

\section{Proteases}

Proteases are protein-hydrolyzing enzymes classified into acidic, neutral, or alkaline groups, based on their optimum $\mathrm{pH}$. They can also be classified into aspartic, cysteine, glutamic, metallo, serine, and threonine protease types based on the amino acids present in their active sites (Singh et al., 2015). These enzymes are widely used in various industries such as detergent, food, and leather (Haddar et al., 2009; George et al., 2014). A thermotolerant, alkali-stable and oxidation resistant protease (CHpro1) was found by functional screening of a metagenomic library constructed from sediments of hot springs in Chumathang area of Ladakh, India (Singh et al., 2015). This enzyme, that showed optimum activity at $\mathrm{pH} 11$ and stability in high alkaline range, could be especially interesting for the detergent industry, as the $\mathrm{pH}$ of laundry detergents is generally in the range of 9.0-12.0. This property, in addition to the resistance in the presence of detergent compounds, like oxidizing agents, and the possibility of working at high wash temperatures (optimum activity at $80^{\circ} \mathrm{C}$ ), makes it a very suitable detergent protease.

\section{Oxidoreductases}

These enzymes catalyze oxidation-reduction reactions, in which hydrogen or oxygen atoms or electrons are transferred between molecules and are important biocatalysts for several industrial processes. From a pharmaceutical point of view, oxidoreductases can act like quorum-quenching enzymes, degrading signal molecules to block quorum-sensing-dependent infection, as reported by Bijtenhoorn et al. (2011), who found a soilderived dehydrogenase/reductase implicated in the decreasing of Pseudomonas aeruginosa biofilm formation and virulence of Caenorhabditis elegans. These enzymes can also be used in food industry as they catalyze oxidation- reduction reactions that can play an important role in taste, flavor and nutritional value of aliments such as virgin olive oil (Peres et al., 2015). Another relevant application of oxidoreductases is their role in decomposing specific recalcitrant contaminants by precipitation or by transforming them to other products, leading to a better final treatment of the waste. Some oxidoreductases that can be used for this purpose include peroxidases, polyphenol oxidases, and estradiol dioxygenases (EDOs) (Durán and Esposito, 2000). Suenaga et al. (2007) constructed a metagenomic library from activated sludge used to treat coke plant wastewater containing various organic pollutants like phenol, mono- and polycyclic nitrogen-containing aromatics or aromatic hydrocarbons, among others. The library was screened for EDOs, using catechol as a substrate, yielding 91 EDO-positive clones, 38 of them were sequenced in order to conduct similarity searches using BLASTX. A polyphenol oxidase enzyme, with alkaline laccase activity and highly soluble expression, showing the optimum activity of $55^{\circ} \mathrm{C}$, was isolated from a functional screening of DNA from mangrove soil (Ye et al., 2010).

\section{COMPARATIVE METAGENOMICS}

The increasing number of metagenomes from high-temperature environments sequenced and the possibility of generating more sequences with a lower cost of time and money has enabled the comparison of metagenomic sequences between and within environments, opening a new field in metagenomics. Comparative metagenomics can enlighten how the microbial community taxa or the metabolic potential vary between sampling locations or time points, as well as explain the influence of several factors, such as high temperatures, in the taxonomical and functional composition of an ecosystem. Comparison of metagenomic data recovered from different high temperature habitats indicates that these communities are different with respect to species abundance and microbial composition. However, some groups of species are more commonly represented, for example, bacterial taxa such as Thermotoga, Deinococcus-Thermus, and Proteobacteria, as well as Archaea, like Methanococcus, Thermoprotei, and Thermococcus (Lewin et al., 2013). The comparison between metagenomes derived from six distantly located hot springs of varying temperature and $\mathrm{pH}$ revealed a wide distribution of four archaeal viral families, Ampullaviridae, Bicaudaviridae, Lipothrixviridae, and Rudiviridae (Gudbergsdóttir et al., 2016). Even though the important role of viruses in high temperature ecosystems has been demonstrated, the comparative studies are limited since the diversity of thermophilic viruses in many hot environments remains unknown, as revealed by Adriaenssens et al. (2015) in the Namib desert hypoliths metagenome, where the majority of the viral sequence reads were classified as unknown.

Comparative metagenomics can also increase our insight into the adaptation of microorganisms to high temperature environments. Xie et al. (2011) compared the sequences obtained from a fosmid metagenomic library of a black smoker chimney 4143-1 in the Mothra hydrothermal vent field at the Juan de Fuca Ridge with metagenomes of different environments, including a biofilm of a carbonate chimney from the Lost City hydrothermal vent field $\left(90^{\circ} \mathrm{C}, \mathrm{pH} 9-11\right.$ fluids). This study revealed that the deep-sea vent chimneys are highly enriched in genes for mismatch repair and homologous recombination, and exhibited a high proportion of transposases. These enzymes, which are critical in horizontal gene transfer, were also abundantly found when comparing the metagenomic data obtained from three different deep-sea hydrothermal vent chimneys (He et al., 2013). This fact supports the previous hypothesis that horizontal gene transfer may be common in the deep-sea vent chimney biosphere and could be an important source of phenotypic diversity (Brazelton and Baross, 2009).

Other comparative studies show that, apart from temperature, $\mathrm{pH}$ is also an important factor in the composition of microbial communities. A comparison of the biodiversity and community composition in eight geographically remote hot springs (temperature range between 61 and $92^{\circ} \mathrm{C}$ and $\mathrm{pH}$ 
between 1.8 and 7) showed a decrease in biodiversity with increasing temperature and decreasing $\mathrm{pH}$ (Menzel et al., 2015). The loss of biodiversity in hot environments with low $\mathrm{pH}$ was also observed by Song et al. (2013), showing a more diverse bacterial population in non-acidic hot springs than in acidic hot springs from the Yunan Province (China).

IMG/M (Markowitz et al., 2014) and MG-RAST (Meyer et al., 2008) are two frequently used metagenomics pipelines to easily perform comparative analysis of microbial communities, and can be explored to find sequences of different high temperature environments, since a considerable number of metagenomes are deposited in their databases. MG-RAST has about 240 thousand data sets containing over 800 billion sequences and more than 36 thousand public metagenomes, including 225 metagenomes (0.61\%) from different thermophilic biomes with temperatures ranging from 52 to $122^{\circ} \mathrm{C}$ obtained by whole shotgun and/or amplicon sequencing (data publicly available at MG-RAST server on August 2016).

Usually, these studies require statistical tools to explore multivariate data, like principal component analysis (PCA), in order to compare and contrast metagenomes from different environments. PCA is one of the most widely used statistical analyses for genomic data as it is a simple and robust data reduction technique that can be applied to large data sets. A more exhaustive description of some of the statistical analysis that can be used to compare metagenomes can be found in the study by Dinsdale et al. (2013). In this study, the metabolic functions of 212 metagenomes, including six different hot springs, were compared between and within environments using different statistical methods. Several tools like STAMP (statistical analysis of metagenomics profiles, Parks et al., 2014) and PRIMER-E can be used for this purpose, allowing the statistical analysis of multivariate data.

\section{FUTURE PERSPECTIVES}

\section{High-Throughput Screening Methods}

Although the new ultra-fast sequencing technologies quickly generate a remarkable number of target gene candidates, functional assays are still needed to confirm them. These assays for protein function represent one of the most reliable and invaluable tools for mining target genes. Thus, developing of high-throughput screening (HTS) methods and improved chromogenic substrates for the detection of thermozymes (Kračun et al., 2015) is a priority for reducing the time invested in primary screening. HTS techniques increase the success of function-based metagenomic screens since they compensate for the often low hit rates in such screens (Ekkers et al., 2012). Apart from conventional high throughput screens, which use microtiter plate wells to store a large number of clones (Ko et al., 2013), microarray-based technologies coupled with microfluidic devices, cell compartmentalization, flow cytometry, and cell sorting are arising as promising new technologies for this purpose (Najah et al., 2014; Meier et al., 2015; VidalMelgosa et al., 2015). Microfluidic technologies are of undeniable interest when it comes to reaching screening rates of a million clones per day (Ufarté et al., 2015). This screening method generally uses fluorogenic substrates (Najah et al., 2013) and it is based on the encapsulation of single clones of the metagenomic library in droplets, followed by the substrate induced geneexpression screening and the fluorescence-activated cell sorting to isolate plasmidic clones containing the genes of interest (Colin et al., 2015; Hosokawa et al., 2015). The main advantages of this ultra-fast screening method are the small volume required (usually picoliters to femtoliters) and the capability of detecting intracellular, extracellular, and membrane proteins. This approach could be used for the screening of thermozymes, as droplets can be incubated at high temperature before proceeding to the screening and fluorescence sorting. In this regard, there is an ongoing FP7 Marie Curie Action named HOTDROPS that involves four companies and four academic partners (including the authors' group) aimed to develop a microfluidics-based ultrahigh-throughput platform for the selection of thermozymes from metagenomics and directed evolution libraries.

\section{Advanced Sequencing}

Until recently, most of the sequences collected in reference databases were related to humans and their pathogens. Currently, the advances in sequencing technologies have enabled the generation of considerable amounts of longer reads in less time. This fact, in addition to the lower per base cost and the development of metagenomics, has produced a relevant increase in the number of genomes sequenced and annotated deposited in databases like GenBank, thus covering a high range of microorganisms from a wide variety of habitats, including high temperature environments. Therefore, the bias in the databases toward microorganisms with clinical or pathogenic interest is decreasing, allowing a better analysis of the populations with metagenomics. Furthermore, metagenomics is becoming a tool in reach of many laboratories with the recent release of new cheaper and smaller devices such as the Oxford Nanopore MinION, a USB flash drive-size sequencer that measures deviations in electrical current as a single DNA strand passes through a protein nanopore (Bayley, 2015). However, this technology presents high error rates compared to the others (Goodwin et al., 2015) and still has to be improved.

Altogether, these breakthrough developments make metagenomics a more affordable and robust tool to explore the taxonomy and the functional diversity of microbial communities. Nevertheless, the complexity of microbial species, together with the limitations of the technology to cover fully whole genome sequences, still pose a great challenge for metagenome research. NGS technologies have limitations and remain at least an order of magnitude more expensive than other conventional microbiological assays, thus samples often must be individually barcoded and pooled into single runs to decrease costs. All these deficiencies will probably disappear as technologies continue developing like they did in the last years, from the end of the human genome sequencing project in 2003 (Collins et al., 2003), up to now.

\section{Advances in Bioinformatics}

Due to the massive amount of metagenome data generated in the last 10 years, infrastructural developments associated 
with managing and serving sequence data are needed. Additionally, the fast growth in the size of data complicates its storage, organization, and distribution. As the volume of metagenomics data keeps growing, new assemblers have been developed, namely MEGAHIT that can assemble large and complex metagenomics data in a time and costefficient way, especially on a single-node server (Li et al., 2015).

New bioinformatic pipelines designed to support researchers involved in functional and taxonomic studies of environmental microbial communities have been released like BioMaS (Fosso et al., 2015), DUDes (Piro et al., 2016), or MOCAT2 (Kultima et al., 2016), among others.

Since there is an increasing number of complex communities sequenced, improved statistical methodology is needed, especially to enhance comparative studies where a large number of covariates (e.g., environmental

\section{REFERENCES}

Acinas, S. G., Marcelino, L. A., Klepac-Ceraj, V., and Polz, M. F. (2004). Divergence and redundancy of $16 \mathrm{~S}$ rRNA sequences in genomes with multiple rrn operons. J. Bacteriol. 186, 2629-2635. doi: 10.1128/JB.186.9.2629-2635.2004

Adriaenssens, E. M., Van Zyl, L., De Maayer, P., Rubagotti, E., Rybicki, E., Tuffin, M., et al. (2015). Metagenomic analysis of the viral community in namib desert hypoliths. Environ. Microbiol. 17, 480-495. doi: 10.1111/1462-2920.12528

Anderson, R. E., Brazelton, W. J., Baross, J. A., Altschul, S., Gish, W., Miller, W., et al. (2011). Using CRISPRs as a metagenomic tool to identify microbial hosts of a diffuse flow hydrothermal vent viral assemblage. FEMS Microbiol. Ecol. 77, 120-133. doi: 10.1111/j.1574-6941.2011.01090.x

Anderson, R. E., Sogin, M. L., Baross, J. A., Anderson, R., Beltrán, M., Hallam, S., et al. (2014). Evolutionary strategies of viruses, bacteria and archaea in hydrothermal vent ecosystems revealed through metagenomics. PLoS ONE 9:e109696. doi: 10.1371/journal.pone.0109696

Angelov, A., Mientus, M., Liebl, S., and Liebl, W. (2009). A two-host fosmid system for functional screening of (meta)genomic libraries from extreme thermophiles. Syst. Appl. Microbiol. 32, 177-185. doi: 10.1016/j.syapm.2008.01.003

Anobom, C. D., Pinheiro, A. S., De-Andrade, R. A., Aguieiras, E. C. G., Andrade, G. C., Moura, M. V., et al. (2014). From structure to catalysis: recent developments in the biotechnological applications of lipases. Biomed Res. Int. 2014:684506. doi: 10.1155/2014/684506

Ashelford, K. E., Chuzhanova, N. A., Fry, J. C., Jones, A. J., and Weightman, A. J. (2005). At least 1 in 20 16S rRNA sequence records currently held in public repositories is estimated to contain substantial anomalies. Appl. Environ. Microbiol. 71, 7724-7736. doi: 10.1128/AEM.71.12.7724-7736.2005

Badhai, J., Ghosh, T. S., and Das, S. K. (2015). Taxonomic and functional characteristics of microbial communities and their correlation with physicochemical properties of four geothermal springs in Odisha, India. Front. Microbiol. 6:1166. doi: 10.3389/fmicb.2015.01166

Baker, G., Gaffar, S., Cowan, D., and Suharto, R. (2001). Bacterial community analysis of Indonesian hot springs. FEMS Microbiol. Lett. 200, 103-109. doi: 10.1016/S0378-1097(01)00207-5

Barns, S. M., Fundyga, R. E., Jeffries, M. W., and Pace, N. R. (1994). Remarkable archaeal diversity detected in a Yellowstone National Park hot spring environment. Proc. Natl. Acad. Sci. U.S.A. 91, 1609-1613. doi: 10.1073/pnas.91.5.1609

Bayley, H. (2015). Nanopore sequencing: from imagination to reality. Clin. Chem. 61, 25-31. doi: 10.1373/clinchem.2014.223016

Becerra, M., Cerdán, M. E., and González-Siso, M. I. (2015). Biobutanol from cheese whey. Microb. Cell Fact. 14, 27. doi: 10.1186/s12934-015-0200-1 or host physiological parameters) are collected for each sample.

\section{AUTHOR CONTRIBUTIONS}

MD did all the data gathering and write-up. ER and MG supervised and reviewed the manuscript, providing comments and guidance during the manuscript development.

\section{FUNDING}

Funding both from the European Union Seventh Framework Programme (FP7/2007-2013) under grant agreement $n^{\circ} 324439$, and from the Xunta de Galicia (Consolidación D.O.G. 10-102012, Contract Number: 2012/118) co-financed by FEDER. The work of MD was supported by a FPU fellowship (Ministerio de Educación Cultura y Deporte) FPU12/05050.

Bhalla, A., Bansal, N., Kumar, S., Bischoff, K. M., and Sani, R. K. (2013). Bioresource technology improved lignocellulose conversion to biofuels with thermophilic bacteria and thermostable enzymes. Bioresour. Technol. 128, 751-759. doi: 10.1016/j.biortech.2012.10.145

Bijtenhoorn, P., Mayerhofer, H., Müller-Dieckmann, J., Utpatel, C., Schipper, C., Hornung, C., et al. (2011). A novel metagenomic short-chain dehydrogenase/reductase attenuates Pseudomonas aeruginosa biofilm formation and virulence on Caenorhabditis elegans. PLoS ONE 6:e26278. doi: 10.1371/journal.pone.0026278

Biver, S., Portetelle, D., and Vandenbol, M. (2013). Characterization of a new oxidant-stable serine protease isolated by functional metagenomics. Springerplus 2:410. doi: 10.1186/2193-1801-2-410

Böhnke, S., and Perner, M. (2015). A function-based screen for seeking RubisCO active clones from metagenomes: novel enzymes influencing RubisCO activity. ISME J. 9, 735-745. doi: 10.1038/ismej.2014.163

Brady, A. L., Sharp, C. E., Grasby, S. E., and Dunfield, P. F. (2015). Anaerobic carboxydotrophic bacteria in geothermal springs identified using stable isotope probing. Front. Microbiol. 6:897. doi: 10.3389/fmicb.2015.00897

Brazelton, W. J., and Baross, J. A. (2009). Abundant transposases encoded by the metagenome of a hydrothermal chimney biofilm. ISME J. 3, 1420-1424. doi: 10.1038/ismej.2009.79

Breitbart, M., Wegley, L., Leeds, S., Schoenfeld, T., and Rohwer, F. (2004). Phage community dynamics in hot springs. Appl. Environ. Microbiol. 70, 1633-1640. doi: 10.1128/AEM.70.3.1633-1640.2004

Brock, T. D., and Freeze, H. (1969). Thermus aquaticus gen. n. and sp. n., a nonsporulating extreme thermophile. J. Bacteriol. 98, 289-297.

Cai, L., Ye, L., Tong, A. H. Y., Lok, S., Zhang, T., Handelsman, J., et al. (2013). Biased diversity metrics revealed by bacterial $16 \mathrm{~S}$ pyrotags derived from different primer sets. PLoS ONE 8:e53649. doi: 10.1371/journal.pone.0053649

Chan, C. S., Chan, K.-G., Tay, Y.-L., Chua, Y.-H., and Goh, K. M. (2015). Diversity of thermophiles in a Malaysian hot spring determined using 16S rRNA and shotgun metagenome sequencing. Front. Microbiol. 6:177. doi: 10.3389/fmicb.2015.00177

Chen, Z. W., Liu, Y. Y., Wu, J. F., She, Q., Jiang, C. Y., and Liu, S. J. (2007). Novel bacterial sulfur oxygenase reductases from bioreactors treating gold-bearing concentrates. Appl. Microbiol. Biotechnol. 74, 688-698. doi: 10.1007/s00253006-0691-0

Cheng, J., Pinnell, L., Engel, K., Neufeld, J. D., and Charles, T. C. (2014). Versatile broad-host-range cosmids for construction of high quality metagenomic libraries. J. Microbiol. Methods 99, 27-34. doi: 10.1016/j.mimet.2014.01.015

Chistoserdova, L. (2010). Recent progress and new challenges in metagenomics for biotechnology. Biotechnol. Lett. 32, 1351-1359. doi: 10.1007/s10529-0100306-9 
Chivian, D., Brodie, E. L., Alm, E. J., Culley, D. E., Dehal, P. S., DeSantis, T. Z., et al. (2008). Environmental genomics reveals a single-species ecosystem deep within Earth. Science 322, 275-278. doi: 10.1126/science.1155495

Chow, J., Kovacic, F., Dall Antonia, Y., Krauss, U., Fersini, F., Schmeisser, C., et al. (2012). The metagenome-derived enzymes LipS and LipT increase the diversity of known lipases. PLoS ONE 7:e47665. doi: 10.1371/journal.pone.0047665

Cole, J. R., Wang, Q., Fish, J. A., Chai, B., McGarrell, D. M., Sun, Y., et al. (2014). Ribosomal database project: data and tools for high throughput rRNA analysis. Nucleic Acids Res. 42, 1-10. doi: 10.1093/nar/gkt1244

Colin, P.-Y., Kintses, B., Gielen, F., Miton, C. M., Fischer, G., Mohamed, M. F., et al. (2015). Ultrahigh-throughput discovery of promiscuous enzymes by picodroplet functional metagenomics. Nat. Commun. 6:10008. doi: 10.1038/ncomms10008

Collins, F. S., Morgan, M., Patrinos, A., Watson, J. D., Olson, M. V., Collins, F. S., et al. (2003). The human genome project: lessons from large-scale biology. Science 300, 286-290. doi: 10.1126/science.1084564

Colman, D. R., Jay, Z. J., Inskeep, W. P., Jennings, R. deM., Maas, K. R., Rusch, D. B., et al. (2016). Novel, deep-branching heterotrophic bacterial populations recovered from thermal spring metagenomes. Front. Microbiol. 7:304. doi: 10.3389/fmicb.2016.00304

Coyotzi, S., Pratscher, J., Murrell, J. C., and Neufeld, J. D. (2016). Targeted metagenomics of active microbial populations with stable-isotope probing. Curr. Opin. Biotechnol. 41, 1-8. doi: 10.1016/j.copbio.2016.02.017

Dadheech, P. K., Glöckner, G., Casper, P., Kotut, K., Mazzoni, C. J., Mbedi, S., et al. (2013). Cyanobacterial diversity in the hot spring, pelagic and benthic habitats of a tropical soda lake. FEMS Microbiol. Ecol. 85, 389-401. doi: 10.1111/1574-6941.12128

De la Torre, J. R., Walker, C. B., Ingalls, A. E., Könneke, M., and Stahl, D. A. (2008). Cultivation of a thermophilic ammonia oxidizing archaeon synthesizing crenarchaeol. Environ. Microbiol. 10, 810-818. doi: 10.1111/j.1462-2920.2007.01506.x

Denonfoux, J., Parisot, N., Dugat-Bony, E., Biderre-Petit, C., Boucher, D., Morgavi, D. P., et al. (2013). Gene capture coupled to high-throughput sequencing as a strategy for targeted metagenome exploration. DNA Res. 20, 185-196. doi: 10.1093/dnares/dst001

Dinsdale, E. A., Edwards, R. A., Bailey, B. A., Tuba, I., Akhter, S., McNair, K., et al. (2013). Multivariate analysis of functional metagenomes. Front. Genet. 4:41. doi: 10.3389/fgene.2013.00041

Dougherty, M. J., D’haeseleer, P., Hazen, T. C., Simmons, B. A., Adams, P. D., and Hadi, M. Z. (2012). Glycoside hydrolases from a targeted compost metagenome, activity-screening and functional characterization. BMC Biotechnol. 12:38. doi: 10.1186/1472-6750-12-38

Dröge, J., and McHardy, A. C. (2012). Taxonomic binning of metagenome samples generated by next-generation sequencing technologies. Brief. Bioinform. 13, 646-655. doi: 10.1093/bib/bbs031

Durán, N., and Esposito, E. (2000). Potential applications of oxidative enzymes and phenoloxidase-like compounds in wastewater and soil treatment: a review. Appl. Catal. B Environ. 28, 83-99. doi: 10.1016/S0926-3373(00) 00168-5

Ekkers, D. M., Cretoiu, M. S., Kielak, A. M., and Van Elsas, J. D. (2012). The great screen anomaly-a new frontier in product discovery through functional metagenomics. Appl. Microbiol. Biotechnol. 93, 1005-1020. doi: 10.1007/s00253-011-3804-3

Fan, X., Liu, X., Huang, R., and Liu, Y. (2012a). Identification and characterization of a novel thermostable pyrethroid-hydrolyzing enzyme isolated through metagenomic approach. Microb. Cell Fact. 11:33. doi: 10.1186/1475-285 9-11-33

Fan, X., Liu, X., and Liu, Y. (2012b). The cloning and characterization of one novel metagenome-derived thermostable esterase acting on $\mathrm{N}$-acylhomoserine lactones. J. Mol. Catal. B Enzym. 83, 29-37. doi: 10.1016/j.molcatb.2012.07.006

Fan, X., Liu, X., Wang, K., Wang, S., Huang, R., and Liu, Y. (2011). Highly soluble expression and molecular characterization of an organic solvent-stable and thermotolerant lipase originating from the metagenome. J. Mol. Catal. B Enzym. 72, 319-325. doi: 10.1016/j.molcatb.2011.07.009

Fancello, L., Trape, S., Robert, C., Boyer, M., Popgeorgiev, N., Raoult, D., et al. (2012). Viruses in the desert: a metagenomic survey of viral communities in four perennial ponds of the Mauritanian Sahara. ISME J. 7, 359-369. doi: 10.1038/ismej.2012.101
Farmer, J. (1998). Thermophiles, early biosphere evolution, and the origin of life on Earth: implications for the exobiological exploration of Mars. J. Geophys. Res. 103, 457-461. doi: 10.1029/98JE01542

Ferrandi, E. E., Sayer, C., Isupov, M. N., Annovazzi, C., Marchesi, C., Iacobone, G., et al. (2015). Discovery and characterization of thermophilic limonene1,2-epoxide hydrolases from hot spring metagenomic libraries. FEBS J. 282, 2879-2894. doi: 10.1111/febs.13328

Ferrer, M., Martínez-Abarca, F., and Golyshin, P. N. (2005). Mining genomes and "metagenomes" for novel catalysts. Curr. Opin. Biotechnol. 16, 588-593. doi: 10.1016/j.copbio.2005.09.001

Ferrer, M., Martínez-Martínez, M., Bargiela, R., Streit, W. R., Golyshina, O. V., and Golyshin, P. N. (2016). Estimating the success of enzyme bioprospecting through metagenomics: current status and future trends. Microb. Biotechnol. 9 , 22-34. doi: 10.1111/1751-7915.12309

Ferris, M. J., Kühl, M., Wieland, A., and Ward, D. M. (2003). Cyanobacterial ecotypes in different optical microenvironments of a $68^{\circ} \mathrm{C}$ hot spring mat community revealed by $16 \mathrm{~S}-23 \mathrm{~S}$ rRNA internal transcribed spacer region variation. Appl. Environ. Microbiol. 69, 2893-2898. doi: 10.1128/AEM.69.5.2893-2898.2003

Fiala, G., and Stetter, K. O. (1986). Pyrococcus furiosus sp. nov. represents a novel genus of marine heterotrophic archaebacteria growing optimally at $100^{\circ} \mathrm{C}$. Arch. Microbiol. 145, 56-61. doi: 10.1007/BF00413027

Finn, R. D., Coggill, P., Eberhardt, R. Y., Eddy, S. R., Mistry, J., Mitchell, A. L., et al. (2015). The Pfam protein families database: towards a more sustainable future. Nucleic Acids Res. 44, D279-D285. doi: 10.1093/nar/gkv1344

Fosso, B., Santamaria, M., Marzano, M., Alonso-Alemany, D., Valiente, G., Donvito, G., et al. (2015). BioMaS: a modular pipeline for Bioinformatic analysis of Metagenomic AmpliconS. BMC Bioinformatics 16:203. doi: 10.1186/s12859-015-0595-Z

Fu, L., He, Y., Xu, F., Ma, Q., Wang, F., and Xu, J. (2015). Characterization of a novel thermostable patatin - like protein from a Guaymas basin metagenomic library. Extremophiles 19, 829-840. doi: 10.1007/s00792-015-0758-x

Fuciños, P., Atanes, E., López-López, O., Solaroli, M., Cerdán, M. E., GonzálezSiso, M. I., et al. (2014). Cloning, expression, purification and characterization of an oligomeric His-tagged thermophilic esterase from Thermus thermophilus HB27. Process Biochem. 49, 927-935. doi: 10.1016/j.procbio.2014.03.006

Gao, G., Wang, A., Gong, B., Li, Q., Liu, Y., He, Z., et al. (2016). A novel metagenome-derived gene cluster from termite hindgut: encoding phosphotransferase system components and high glucose tolerant glucosidase. Enzyme Microb. Technol. 84, 24-31. doi: 10.1016/j.enzmictec.2015.12.005

George, N., Singh, P., Kumar, V., Puri, N., and Gupta, N. (2014). Approach to ecofriendly leather: characterization and application of an alkaline protease for chemical free dehairing of skins and hides at pilot scale. J. Clean. Prod. 79, 249-257. doi: 10.1016/j.jclepro.2014.05.046

Gerbl, F. W., Weidler, G. W., Wanek, W., Erhardt, A., and Stan-Lotter, H. (2014). Thaumarchaeal ammonium oxidation and evidence for a nitrogen cycle in a subsurface radioactive thermal spring in the Austrian Central Alps. Front. Microbiol. 5:225. doi: 10.3389/fmicb.2014.00225

Ghelani, A., Patel, R., Mangrola, A., and Dudhagara, P. (2015). Cultivationindependent comprehensive survey of bacterial diversity in Tulsi Shyam Hot Springs, India. Genomics Data 4, 54-56. doi: 10.1016/j.gdata.2015. 03.003

Gladden, J. M., Allgaier, M., Miller, C. S., Hazen, T. C., VanderGheynst, J. S., Hugenholtz, P., et al. (2011). Glycoside hydrolase activities of thermophilic bacterial consortia adapted to switchgrass. Appl. Environ. Microbiol. 77, 5804-5812. doi: 10.1128/AEM.00032-11

Goodwin, S., Gurtowski, J., Ethe-Sayers, S., Deshpande, P., Schatz, M., and McCombie, W. R. (2015). Oxford Nanopore sequencing and de novo assembly of a eukaryotic genome. Genome Res. 25, 1750-1756. doi: 10.1101/ 013490

Graham, J. E., Clark, M. E., Nadler, D. C., Huffer, S., Chokhawala, H. A., Rowland, S. E., et al. (2011). Identification and characterization of a multidomain hyperthermophilic cellulase from an archaeal enrichment. Nat. Commun. 2:375. doi: 10.1038/ncomms1373

Gudbergsdóttir, S. R., Menzel, P., Krogh, A., Young, M., and Peng, X. (2016). Novel viral genomes identified from six metagenomes reveal wide distribution of archaeal viruses and high viral diversity in terrestrial hot springs. Environ. Microbiol. 18, 863-874. doi: 10.1111/1462-2920.13079 
Gupta, P., Manjula, A., Rajendhran, J., Gunasekaran, P., and Vakhlu, J. (2016). Comparison of metagenomic DNA extraction methods for soil sediments of high elevation Puga hot spring in Ladakh, India to explore bacterial diversity. Geomicrobiol. J. doi: 10.1080/01490451.2015.1128995. [Epub ahead of print].

Gupta, R., Govil, T., Capalash, N., and Sharma, P. (2012). Characterization of a glycoside hydrolase family $1 \beta$-galactosidase from hot spring metagenome with transglycosylation activity. Appl. Biochem. Biotechnol. 168, 1681-1693. doi: 10.1007/s12010-012-9889-Z

Haddar, A., Agrebi, R., Bougatef, A., Hmidet, N., Sellami-kamoun, A., and Nasri, M. (2009). Bioresource technology two detergent stable alkaline serineproteases from Bacillus mojavensis A21: purification, characterization and potential application as a laundry detergent additive. Bioresour. Technol. 100, 3366-3373. doi: 10.1016/j.biortech.2009.01.061

Handelsman, J. (2004). Metagenomics: application of genomics to uncultured microorganisms. Microbiol. Mol. Biol. Rev. 68, 669-685. doi: 10.1128/MBR.68.4.669

He, Y., Xiao, X., and Wang, F. (2013). Metagenome reveals potential microbial degradation of hydrocarbon coupled with sulfate reduction in an oilimmersed chimney from Guaymas Basin. Front. Microbiol. 4:148. doi: 10.3389/fmicb.2013.00148

Hedlund, B. P., Dodsworth, J. A., Cole, J. K., and Panosyan, H. H. (2013). An integrated study reveals diverse methanogens, Thaumarchaeota, and yet-uncultivated archaeal lineages in Armenian hot springs. Antonie van Leeuwenhoek 104, 71-82. doi: 10.1007/s10482-013-9927-z

Hosokawa, M., Hoshino, Y., Nishikawa, Y., Hirose, T., Yoon, D. H., Mori, T., et al. (2015). Droplet-based microfluidics for high-throughput screening of a metagenomic library for isolation of microbial enzymes. Biosens. Bioelectron. 67, 379-385. doi: 10.1016/j.bios.2014.08.059

Huang, Q., Jiang, H., Briggs, B. R., Wang, S., Hou, W., Li, G., et al. (2013). Archaeal and bacterial diversity in acidic to circumneutral hot springs in the Philippines. FEMS Microbiol. Ecol. 85, 452-464. doi: 10.1111/1574-6941. 12134

Hug, K., Maher, W. A., Stott, M. B., Krikowa, F., Foster, S., and Moreau, J. W. (2014). Microbial contributions to coupled arsenic and sulfur cycling in the acid-sulfide hot spring Champagne Pool, New Zealand. Front. Microbiol. 5:569. doi: $10.3389 /$ fmicb.2014.00569

Huson, D., Mitra, S., and Ruscheweyh, H. (2011). Integrative analysis of environmental sequences using MEGAN4. Genome Res. 21, 1552-1560. doi: 10.1101/gr.120618.111

Ilmberger, N., Meske, D., Juergensen, J., Schulte, M., Barthen, P., Rabausch, U., et al. (2012). Metagenomic cellulases highly tolerant towards the presence of ionic liquids - Linking thermostability and halotolerance. Appl. Microbiol. Biotechnol. 95, 135-146. doi: 10.1007/s00253-011-3732-2

Inskeep, W. P., Jay, Z. J., Herrgard, M. J., Kozubal, M. A., Rusch, D. B., Tringe, S. G., et al. (2013). Phylogenetic and functional analysis of metagenome sequence from high-temperature archaeal habitats demonstrate linkages between metabolic potential and geochemistry. Front. Microbiol. 4:95. doi: 10.3389/fmicb.2013.00095

Inskeep, W. P., Rusch, D. B., Jay, Z. J., Herrgard, M. J., Kozubal, M. A., Richardson, T. H., et al. (2010). Metagenomes from high-temperature chemotrophic systems reveal geochemical controls on microbial community structure and function. PLOS ONE 5:e9773. doi: 10.1371/journal.pone.00 09773

Jabbour, D., Sorger, A., and Sahm, K. (2013). A highly thermoactive and salt-tolerant $\alpha$-amylase isolated from a pilot-plant biogas reactor. Appl. Microbiol. Biotechnol. 97, 2971-2978. doi: 10.1007/s00253-0124194-x

Kanehisa, M., Sato, Y., Kawashima, M., Furumichi, M., and Tanabe, M. (2016). KEGG as a reference resource for gene and protein annotation. Nucleic Acids Res. 44, D457-D462. doi: 10.1093/nar/gkv1070

Kang, C.-H., Oh, K.-H., Lee, M.-H., Oh, T.-K., Kim, B. H., and Yoon, J.H. (2011). A novel family VII esterase with industrial potential from compost metagenomic library. Microb. Cell Fact. 10:41. doi: 10.1186/14752859-10-41

Kim, H. J., Jeong, Y. S., Jung, W. K., Kim, S. K., Lee, H. W., Kahng, H. Y., et al. (2015). Characterization of novel family IV esterase and family I.3 lipase from an oil-polluted mud flat metagenome. Mol. Biotechnol. 57, 781-792. doi: $10.1007 /$ s12033-015-9871-4
Kim, K. H., and Bae, J. W. (2011). Amplification methods bias metagenomic libraries of uncultured single-stranded and double-stranded DNA viruses. Appl. Environ. Microbiol. 77, 7663-7668. doi: 10.1128/AEM.00289-11

Klatt, C. G., Inskeep, W. P., Herrgard, M. J., Jay, Z. J., Rusch, D. B., Tringe, S. G., et al. (2013). Community structure and function of high-temperature chlorophototrophic microbial mats inhabiting diverse geothermal environments. Front. Microbiol. 4:106. doi: 10.3389/fmicb.2013. 00106

Klatt, C. G., Wood, J. M., Rusch, D. B., Bateson, M. M., Hamamura, N., Heidelberg, J. F., et al. (2011). Community ecology of hot spring cyanobacterial mats: predominant populations and their functional potential. ISME J. 5, 1262-1278. doi: $10.1038 /$ ismej.2011.73

Ko, K. C., Han, Y., Cheong, D. E., Choi, J. H., and Song, J. J. (2013). Strategy for screening metagenomic resources for exocellulase activity using a robotic, high-throughput screening system. J. Microbiol. Methods 94, 311-316. doi: 10.1016/j.mimet.2013.07.010

Kotlar, H. K., Lewin, A., Johansen, J., Throne-Holst, M., Haverkamp, T., Markussen, S., et al. (2011). High coverage sequencing of DNA from microorganisms living in an oil reservoir 2.5 kilometres subsurface. Environ. Microbiol. Rep. 3, 674-681. doi: 10.1111/j.1758-2229.2011. 00279.x

Kozubal, M. A., Romine, M., Jennings, R. deM., Jay, Z. J., Tringe, S. G., Rusch, D. B., et al. (2013). Geoarchaeota: a new candidate phylum in the Archaea from hightemperature acidic iron mats in Yellowstone National Park. ISME J. 7, 622-634. doi: 10.1038/ismej.2012.132

Kračun, S. K., Schückel, J., Westereng, B., Thygesen, L. G., Monrad, R. N., Eijsink, V. G. H., et al. (2015). A new generation of versatile chromogenic substrates for high-throughput analysis of biomass-degrading enzymes. Biotechnol. Biofuels 8:70. doi: 10.1186/s13068-015-0250-y

Kultima, J. R., Coelho, L. P., Forslund, K., Huerta-Cepas, J., Li, S. S., Driessen, M., et al. (2016). MOCAT2: a metagenomic assembly, annotation and profiling framework. Bioinformatics 32, 2520-2523. doi: 10.1093/bioinformatics/btw183

Kumar, S., Krishnani, K. K., Bhushan, B., and Brahmane, M. P. (2015). Metagenomics: retrospect and prospects in high throughput age. Biotechnol. Res. Int. 2015:121735. doi: 10.1155/2015/121735

Kumar, V., Marín-Navarro, J., and Shukla, P. (2016). Thermostable microbial xylanases for pulp and paper industries: trends, applications and further perspectives. World J. Microbiol. Biotechnol. 32, 34. doi: 10.1007/s11274-0152005-0

Kwon, E. J., Jeong, Y. S., Kim, Y. H., Kim, S. K., Na, H. B., Kim, J., et al. (2010). Construction of a metagenomic library from compost and screening of cellulase- and xylanase-positive clones. J. Appl. Biol. Chem. 53, 702-708. doi: $10.3839 /$ jksabc.2010.106

Lam, K. N., Cheng, J., Engel, K., Neufeld, J. D., and Charles, T. C. (2015). Current and future resources for functional metagenomics. Front. Microbiol.6:1196. doi: 10.3389/fmicb.2015.01196

Leis, B., Angelov, A., Mientus, M., Li, H., Pham, V. T. T., Lauinger, B., et al. (2015). Identification of novel esterase-active enzymes from hot environments by use of the host bacterium Thermus thermophilus. Front. Microbiol. 6:275. doi: $10.3389 /$ fmicb. 2015.00275

Lewin, A., Wentzel, A., and Valla, S. (2013). Metagenomics of microbial life in extreme temperature environments. Curr. Opin. Biotechnol. 24, 516-525. doi: 10.1016/j.copbio.2012.10.012

Li, A., Chu, Y., Wang, X., Ren, L., Yu, J., Liu, X., et al. (2013a). A pyrosequencingbased metagenomic study of methane-producing microbial community in solid-state biogas reactor. Biotechnol. Biofuels 6:3. doi: 10.1186/17546834-6-3

Li, D., Greenfield, P., Rosewarne, C. P., and Midgley, J. (2013b). Draft genome sequence of Thermoanaerobacter sp. Strain A7A, reconstructed from a metagenome obtained from a high- temperature hydrocarbon reservoir in the Bass Strait, Australia. Genome Announc. 1, e00701-13. doi: 10.1128/genomeA.00701-13

Li, D., Liu, C.-M., Luo, R., Sadakane, K., and Lam, T.-W. (2015). MEGAHIT: an ultra-fast single-node solution for large and complex metagenomics assembly via succinct de Bruijn graph. Bioinformatics 31, 1674-1676. doi: 10.1093/bioinformatics/btv033

Lin, K.-H., Liao, B.-Y., Chang, H.-W., Huang, S.-W., Chang, T.-Y., Yang, C.-Y., et al. (2015). Metabolic characteristics of dominant microbes and key rare 
species from an acidic hot spring in Taiwan revealed by metagenomics. BMC Genomics 16:1029. doi: 10.1186/s12864-015-2230-9

Liu, B., Gibbons, T., Ghodsi, M., and Pop, M. (2010). "MetaPhyler: taxonomic profiling for metagenomic sequences," 2010 IEEE International Conference on Bioinformatics and Biomedicine (BIBM) (Hong Kong), 95-100.

Liu, L., Li, Y., Li, S., Hu, N., He, Y., Pong, R., et al. (2012). Comparison of next-generation sequencing systems. J. Biomed. Biotechnol. 2012:251364. doi: $10.1155 / 2012 / 251364$

Liu, W. T., Marsh, T. L., Cheng, H., and Forney, L. J. (1997). Characterization of microbial diversity by determining terminal restriction fragment length polymorphisms of genes encoding 16S rRNA. Appl. Environ. Microbiol. 63, 4516-4522.

Liu, Z., Zhao, C., Deng, Y., Huang, Y., and Liu, B. (2015). Characterization of a thermostable recombinant $\beta$-galactosidase from a thermophilic anaerobic bacterial consortium YTY-70. Biotechnol. Biotechnol. Equip. 29, 547-554. doi: 10.1080/13102818.2015.1015244

Lombard, V., Ramulu, H. G., Drula, E., Coutinho, P. M., and Henrissat, B. (2014). The carbohydrate-active enzymes database (CAZy) in 2013. Nucleic Acids Res. 42, 490-495. doi: 10.1093/nar/gkt1178

López-López, O., Cerdán, M. E., and González Siso, M. I. (2014). New extremophilic lipases and esterases from metagenomics. Curr. Protein Pept. Sci. 15, 445-455. doi: 10.2174/1389203715666140228153801

López-López, O., Cerdán, M.-E., and González-Siso, M.-I. (2015a). Thermus thermophilus as a source of thermostable lipolytic enzymes. Microorganisms 3, 792-808. doi: 10.3390/microorganisms3040792

López-López, O., Knapik, K., Cerdán, M. E., and González-Siso, M. I. (2015b). Metagenomics of an alkaline hot spring in Galicia (Spain): microbial diversity analysis and screening for novel lipolytic enzymes. Front. Microbiol. 6:1291. doi: 10.3389/fmicb.2015.01291

Luo, C., Tsementzi, D., Kyrpides, N., Read, T., Konstantinidis, K. T., Nelson, K., et al. (2012). Direct comparisons of Illumina vs. Roche 454 sequencing technologies on the same microbial community DNA sample. PLoS ONE 7:e30087. doi: 10.1371/journal.pone.0030087

Macwan, A. S., Javed, S., and Kumar, A. (2011). Isolation of a novel thermostable dehydrochlorinase (LinA) from a soil metagenome. 3 Biotech 1, 193-198. doi: 10.1007/s13205-011-0012-x

Mangrola, A., Dudhagara, P., Koringa, P., Joshi, C. G., Parmar, M., and Patel, R. (2015a). Deciphering the microbiota of Tuwa hot spring, India using shotgun metagenomic sequencing approach. Genomics Data 4, 153-155. doi: 10.1016/j.gdata.2015.04.014

Mangrola, A. V., Dudhagara, P., Koringa, P., Joshi, C. G., and Patel, R. K. (2015b). Shotgun metagenomic sequencing based microbial diversity assessment of Lasundra hot spring, India. Genomics Data 4, 73-75. doi: 10.1016/j.gdata.2015.03.005

Manoharan, L., Kushwaha, S. K., Hedlund, K., and Ahrén, D. (2015). Captured metagenomics: large-scale targeting of genes based on "sequence capture" reveals functional diversity in soils. DNA Res. 22, 451-460. doi: 10.1093/dnares/dsv026

Markowitz, V. M., Chen, I. M. A., Chu, K., Szeto, E., Palaniappan, K., Pillay, M., et al. (2014). IMG/M 4 version of the integrated metagenome comparative analysis system. Nucleic Acids Res. 42, 568-573. doi: 10.1093/nar/ gkt919

Martins, L. F., Antunes, L. P., Pascon, R. C., de Oliveira, J. C. F., Digiampietri, L. A., Barbosa, D., et al. (2013). Metagenomic analysis of a tropical composting operation at the São Paulo zoo park reveals diversity of biomass degradation functions and organisms. PLoS ONE 8:e61928. doi: 10.1371/journal.pone.0061928

Maruthamuthu, M., Jiménez, D. J., Stevens, P., and Van Elsas, J. D. (2016). A multisubstrate approach for functional metagenomics-based screening for (hemi) cellulases in two wheat straw- degrading microbial consortia unveils novel thermoalkaliphilic enzymes. BMC Genomics 17:86. doi: 10.1186/s12864-0162404-0

Mayumi, D., Akutsu-Shigeno, Y., Uchiyama, H., Nomura, N., and NakajimaKambe, T. (2008). Identification and characterization of novel poly(DLlactic acid) depolymerases from metagenome. Appl. Microbiol. Biotechnol. 79, 743-750. doi: 10.1007/s00253-008-1477-3

Meddeb-Mouelhi, F., Kelly, J., and Beauregard, M. (2014). Enzyme and Microbial Technology A comparison of plate assay methods for detecting extracellular cellulase and xylanase activity. Enzyme Microb. Technol. 66, 16-19. doi: 10.1016/j.enzmictec.2014.07.004

Mehetre, G. T., Paranjpe, A. S., Dastager, S. G., and Dharne, M. S. (2016). Complete metagenome sequencing based bacterial diversity and functional insights from basaltic hot spring of Unkeshwar, Maharashtra, India. Genomics Data 7, 140-143. doi: 10.1016/j.gdata.2015.12.031

Meier, M. J., Paterson, E. S., and Lambert, I. B. (2015). Use of substrateinduced gene expression in metagenomic analysis of an aromatic hydrocarbon-contaminated soil. Appl. Environ. Microbiol. 82, 897-909. doi: 10.1128/AEM.03306-15

Meilleur, C., Hupé, J. F., Juteau, P., and Shareck, F. (2009). Isolation and characterization of a new alkali-thermostable lipase cloned from a metagenomic library. J. Ind. Microbiol. Biotechnol. 36, 853-861. doi: 10.1007/s10295-009-0562-7

Menzel, P., Gudbergsdóttir, S. R., Rike, A. G., Lin, L., Zhang, Q., Contursi, P., et al. (2015). Comparative metagenomics of eight geographically remote terrestrial hot springs. Microb. Ecol. 70, 411-424. doi: 10.1007/s00248-015-0576-9

Meyer, F., Paarmann, D., D’Souza, M., Olson, R., Glass, E., Kubal, M., et al. (2008). The metagenomics RAST server-a public resource for the automatic phylogenetic and functional analysis of metagenomes. BMC Bioinformatics 9:386. doi: 10.1186/1471-2105-9-386

Miller, C. S., Baker, B. J., Thomas, B. C., Singer, S. W., Banfield, J. F., Pace, N., et al. (2011). EMIRGE: reconstruction of full-length ribosomal genes from microbial community short read sequencing data. Genome Biol. 12:R44. doi: 10.1186/gb-2011-12-5-r44

Mirete, S., Morgante, V., and González-Pastor, J. E. (2016). Functional metagenomics of extreme environments. Curr. Opin. Biotechnol. 38, 143-149. doi: 10.1016/j.copbio.2016.01.017

Mitchell, K. R., and Takacs-Vesbach, C. D. (2008). A comparison of methods for total community DNA preservation and extraction from various thermal environments. J. Ind. Microbiol. Biotechnol. 35, 1139-1147. doi: 10.1007/s10295-008-0393-y

Morrison, L. E., and Tanner, F. W. (1922). Studies on Thermophilic Bacteria: I. Aerobic Thermophilic Bacteria from Water. J. Bacteriol. 7, 343-366.

Moser, M. J., DiFrancesco, R. A., Gowda, K., Klingele, A. J., Sugar, D. R., Stocki, S., et al. (2012). Thermostable DNA polymerase from a viral metagenome is a potent RT-PCR enzyme. PLOS ONE 7:e38371. doi: 10.1371/journal.pone.0038371

Muyzer, G., De Waal, E. C., and Uitterlinden, A. G. (1993). Profiling of complex microbial populations by denaturing gradient gel electrophoresis analysis of polymerase chain reaction-amplified genes coding for 16S rRNA. Appl. Env. Microbiol. 59, 695-700.

Najah, M., Calbrix, R., Mahendra-Wijaya, I. P., Beneyton, T., Griffiths, A. D., and Drevelle, A. (2014). Droplet-based microfluidics platform for ultra-highthroughput bioprospecting of cellulolytic microorganisms. Chem. Biol. 21, 1722-1732. doi: 10.1016/j.chembiol.2014.10.020

Najah, M., Mayot, E., Mahendra-Wijaya, I. P., Griffiths, A. D., Ladame, S., and Drevelle, A. (2013). New glycosidase substrates for droplet-based microfluidic screening. Anal. Chem. 85, 9807-9814. doi: 10.1021/ac4022709

Nakai, R., Abe, T., Takeyama, H., and Naganuma, T. (2011). Metagenomic analysis of $0.2-\mu \mathrm{m}$-passable microorganisms in deep-sea hydrothermal fluid. Mar. Biotechnol. 13, 900-908. doi: 10.1007/s10126-0109351-6

Namiki, T., Hachiya, T., Tanaka, H., and Sakakibara, Y. (2012). MetaVelvet: an extension of Velvet assembler to de novo metagenome assembly from short sequence reads. Nucleic Acids Res. 40:e155. doi: 10.1093/nar/gks678

Neveu, J., Regeard, C., and Dubow, M. S. (2011). Isolation and characterization of two serine proteases from metagenomic libraries of the Gobi and Death Valley deserts. Appl. Microbiol. Biotechnol. 91, 635-644. doi: 10.1007/s00253011-3256-9

Olsen, G. J., Lane, D. J., Giovannoni, S. J., Pace, N. R., and Stahl, D. A. (1986). Microbial ecology and evolution: a ribosomal RNA approach. Annu. Rev. Microbiol. 40, 337-365. doi: 10.1146/annurev.mi.40.100186.002005

Overbeek, R., Olson, R., Pusch, G. D., Olsen, G. J., Davis, J. J., Disz, T., et al. (2014). The SEED and the Rapid Annotation of microbial genomes using Subsystems Technology (RAST). Nucleic Acids Res. 42, 206-214. doi: 10.1093/nar/gkt1226

Panda, A. K., Bisht, S. S., Kumar, N. S., and De Mandal, S. (2015). Investigations on microbial diversity of Jakrem hot spring, Meghalaya, India 
using cultivation-independent approach. Genomics Data 4, 156-157. doi: 10.1016/j.gdata.2015.04.016

Pap, B., Györkei, Á., Boboescu, I. Z., Nagy, I. K., Bíró, T., Kondorosi, É., et al. (2015). Temperature-dependent transformation of biogas-producing microbial communities points to the increased importance of hydrogenotrophic methanogenesis under thermophilic operation. Bioresour. Technol. 177, 375-380. doi: 10.1016/j.biortech.2014.11.021

Parks, D. H., Tyson, G. W., Hugenholtz, P., and Beiko, R. G. (2014). STAMP: statistical analysis of taxonomic and functional profiles. Bioinformatics 30, 3123-3124. doi: 10.1093/bioinformatics/btu494

Peng, Y., Leung, H. C. M., Yiu, S. M., and Chin, F. Y. L. (2012). IDBA-UD: a de novo assembler for single-cell and metagenomic sequencing data with highly uneven depth. Bioinformatics 28, 1420-1428. doi: 10.1093/bioinformatics/bts174

Peres, F., Martins, L. L., and Ferreira-Dias, S. (2015). Influence of enzymes and technology on virgin olive oil composition. Crit. Rev. Food Sci. Nutr. doi: 10.1080/10408398.2015.1092107. [Epub ahead of print].

Pessela, B. C. C., Torres, R., Fuentes, M., Mateo, C., Filho, M., Carrascosa, A. V., et al. (2004). A simple strategy for the purification of large thermophilic proteins overexpressed in mesophilic microorganisms: application to multimeric enzymes from Thermus sp. strain T2 expressed in Escherichia coli. Biotechnol. Prog. 20, 1507-1511. doi: 10.1021/bp049785t

Pham, V. H. T., and Kim, J. (2012). Cultivation of unculturable soil bacteria. Trends Biotechnol. 30, 475-484. doi: 10.1016/j.tibtech.2012.05.007

Piro, V. C., Lindner, M. S., and Renard, B. Y. (2016). DUDes: a top-down taxonomic profiler for metagenomics. Bioinformatics 32, 2272-2280. doi: 10.1093/bioinformatics/btw150

Prokofeva, M. I., Kublanov, I. V., Nercessian, O., Tourova, T. P., Kolganova, T. V., Lebedinsky, A. V., et al. (2005). Cultivated anaerobic acidophilic/acidotolerant thermophiles from terrestrial and deep-sea hydrothermal habitats. Extremophiles 9, 437-448. doi: 10.1007/s00792-005-0461-4

Purcell, D., Sompong, U., Yim, L. C., Barraclough, T. G., Peerapornpisal, Y., and Pointing, S. B. (2007). The effects of temperature, $\mathrm{pH}$ and sulphide on the community structure of hyperthermophilic streamers in hot springs of northern Thailand. FEMS Microbiol. Ecol. 60, 456-466. doi: 10.1111/j.15746941.2007.00302.x

Quast, C., Pruesse, E., Yilmaz, P., Gerken, J., Schweer, T., Yarza, P., et al. (2013). The SILVA ribosomal RNA gene database project: improved data processing and web-based tools. Nucleic Acids Res. 41, 590-596. doi: 10.1093/nar/gks1219

Rademacher, A., Zakrzewski, M., Schlüter, A., Schönberg, M., Szczepanowski, R., Goesmann, A., et al. (2012). Characterization of microbial biofilms in a thermophilic biogas system by high-throughput metagenome sequencing. FEMS Microbiol. Ecol. 79, 785-799. doi: 10.1111/j.1574-6941.2011.01265.x

Rhee, J.-K., Ahn, D.-G., Kim, Y.-G., and Oh, J.-W. (2005). New thermophilic and thermostable esterase with sequence similarity to the hormone-sensitive lipase family, cloned from a metagenomic library. Appl. Environ. Microbiol. 71, 817-825. doi: 10.1128/AEM.71.2.817-825.2005

Roh, C., and Schmid, R. D. (2013). Isolation of an organic solvent-tolerant lipolytic enzyme from uncultivated microorganism. Appl. Biochem. Biotechnol. 171, 1750-1758. doi: 10.1007/s12010-013-0464-Z

Rohwer, F., Prangishvili, D., and Lindell, D. (2009). Roles of viruses in the environment. Environ. Microbiol. 11, 2771-2774. doi: 10.1111/j.14622920.2009.02101.x

Rozanov, A. S., Bryanskaya, A. V., Malup, T. K., Meshcheryakova, I. A., Lazareva, E. V., Taran, O. P., et al. (2014). Molecular analysis of the benthos microbial community in Zavarzin thermal spring (Uzon Caldera, Kamchatka, Russia). BMC Genomics 15:S12. doi: 10.1186/1471-2164-15-S12-S12

Sahm, K., John, P., Nacke, H., Wemheuer, B., Grote, R., Daniel, R., et al. (2013). High abundance of heterotrophic prokaryotes in hydrothermal springs of the Azores as revealed by a network of 16S rRNA gene-based methods. Extremophiles 17, 649-662. doi: 10.1007/s00792-013-0548-2

Sangwan, N., Lambert, C., Sharma, A., Gupta, V., Khurana, P., Khurana, J. P., et al. (2015). Arsenic rich Himalayan hot spring metagenomics reveal genetically novel predator-prey genotypes. Environ. Microbiol. Rep. 7, 812-823. doi: 10.1111/1758-2229.12297

Sarmiento, F., Peralta, R., and Blamey, J. M. (2015). Cold and hot extremozymes: industrial relevance and current trends. Front. Bioeng. Biotechnol. 3:148. doi: 10.3389/fbioe. 2015.00148
Sathya, T. A., and Khan, M. (2014). Diversity of glycosyl hydrolase enzymes from metagenome and their application in food industry. J. Food Sci. 79, R2149-R2156. doi: 10.1111/1750-3841.12677

Schmidt, T. M., Delong, E. F., and Pace, N. R. (1991). Analysis of a marine picoplankton community by $16 \mathrm{~S}$ rRNA gene cloning and sequencing. $J$. Bacteriol. 173, 4371-4378.

Schoenfeld, T., Patterson, M., Richardson, P. M., Wommack, K. E., Young, M., and Mead, D. (2008). Assembly of viral metagenomes from yellowstone hot springs. Appl. Environ. Microbiol. 74, 4164-4174. doi: 10.1128/AEM. 02598-07

Schoenfeld, T. W., Murugapiran, S. K., Dodsworth, J. A., Floyd, S., Lodes, M. Mead, D. A., et al. (2013). Lateral gene transfer of family a DNA polymerases between thermophilic viruses, aquificae, and apicomplexa. Mol. Biol. Evol. 30, 1653-1664. doi: 10.1093/molbev/mst078

Schröder, C., Elleuche, S., Blank, S., and Antranikian, G. (2014). Characterization of a heat-active archaeal $\beta$-glucosidase from a hydrothermal spring metagenome. Enzyme Microb. Technol. 57, 48-54. doi: 10.1016/j.enzmictec.2014.01.010

Sen, S. K., Jana, A., Bandyopadhyay, P., Das Mohapatra, P. K., and Raut, S. (2016). Thermostable amylase production from hot spring isolate Exiguobacterium sp: a promising agent for natural detergents. Sustain. Chem. Pharm. 3, 59-68. doi: 10.1016/j.scp.2016.04.002

Servín-Garcidueñas, L. E., Peng, X., Garrett, R. A., and Martínez-Romero, E. (2013). Genome sequence of a novel archaeal rudivirus recovered from a mexican hot spring. Genome Announc. 1, e00040-12. doi: 10.1128/genomeA.00040-12

Shah, N., Tang, H., Doak, T. G., and Ye, Y. (2011). Comparing bacterial communities inferred from $16 \mathrm{~S}$ rRNA gene sequencing and shotgun metagenomics. Pac. Symp. Biocomput. 17, 165-176. doi: $10.1142 / 9789814335058$

Shao, H., Xu, L., and Yan, Y. (2013). Isolation and characterization of a thermostable esterase from a metagenomic library. J. Ind. Microbiol. Biotechnol. 40, 1211-1222. doi: 10.1007/s10295-013-1317-Z

Sharma, A., Gilbert, J. A., and Lal, R. (2016). (Meta)genomic insights into the pathogenome of Cellulosimicrobium cellulans. Sci. Rep. 6:25527. doi: $10.1038 /$ srep 25527

Sharma, A., Jani, K., Shouche, Y. S., and Pandey, A. (2015). Microbial diversity of the Soldhar hot spring, India, assessed by analyzing 16S rRNA and protein-coding genes. Ann. Microbiol. 65, 1323-1332. doi: 10.1007/s13213-0140970-4

Sharma, N., Tanksale, H., Kapley, A., and Purohit, H. J. (2012). Mining the metagenome of activated biomass of an industrial wastewater treatment plant by a novel method. Indian J. Microbiol. 52, 538-543. doi: 10.1007/s12088-0120263-1

Sharpton, T. J. (2014). An introduction to the analysis of shotgun metagenomic data. Front. Plant Sci. 5:209. doi: 10.3389/fpls.2014.00209

Shi, H., Zhang, Y., Li, X., Huang, Y., Wang, L., Wang, Y., et al. (2013). A novel highly thermostable xylanase stimulated by $\mathrm{Ca}^{2+}$ from Thermotoga thermarum: cloning, expression and characterization. Biotechnol. Biofuels 6:26. doi: 10.1186/1754-6834-6-26

Silva, G. G. Z., Green, K. T., Dutilh, B. E., and Edwards, R. A. (2015). SUPERFOCUS: a tool for agile functional analysis of shotgun metagenomic data. Bioinformatics 32, 354-361. doi: 10.1093/bioinformatics/btv584

Singh, A., and Subudhi, E. (2016). Profiling of microbial community of Odisha hot spring based on metagenomic sequencing. Genomics Data 7, 187-188. doi: 10.1016/j.gdata.2016.01.004

Singh, R., Chopra, C., and Kumar, V. (2015). Purification and characterization of CHpro1, a thermotolerant, alkali-stable and oxidation-resisting protease of Chumathang hotspring. Sci. Bull. 60, 1252-1260. doi: 10.1007/s11434-0150834-8

Singh, R., Dhawan, S., Singh, K., and Kaur, J. (2012). Cloning, expression and characterization of a metagenome derived thermoactive/thermostable pectinase. Mol. Biol. Rep. 39, 8353-8361. doi: 10.1007/s11033-012-1685-x

Singhania, R. R., Patel, A. K., Sukumaran, R. K., Larroche, C., and Pandey, A. (2013). Role and significance of beta-glucosidases in the hydrolysis of cellulose for bioethanol production. Bioresour. Technol. 127, 500-507. doi: 10.1016/j.biortech.2012.09.012 
Sonbol, S. A., Ferreira, A. J. S., and Siam, R. (2016). Red Sea Atlantis II brine pool nitrilase with unique thermostability profile and heavy metal tolerance. $B M C$ Biotechnol. 16:14. doi: 10.1186/s12896-016-0244-2

Song, Z.-Q., Chen, J.-Q., Jiang, H.-C., Zhou, E.-M., Tang, S.-K., Zhi, X.-Y., et al. (2010). Diversity of Crenarchaeota in terrestrial hot springs in Tengchong, China. Extremophiles 14, 287-296. doi: 10.1007/s00792-010-0307-6

Song, Z.-Q., Wang, F.-P., Zhi, X.-Y., Chen, J.-Q., Zhou, E.-M., Liang, F., et al. (2013). Bacterial and archaeal diversities in Yunnan and Tibetan hot springs, China. Environ. Microbiol. 15, 1160-1175. doi: 10.1111/1462-2920.12025

Stamps, B. W., Corsetti, F. A., Spear, J. R., and Stevenson, B. S. (2014). Draft genome of a novel Chlorobi member assembled by tetranucleotide binning of a hot spring metagenome. Genome Announc. 2, e00897-e00814. doi: 10.1128/genomeA.00897-14.Copyright

Stetter, K. O. (2006). Hyperthermophiles in the history of life. Philos. Trans. R. Soc. Lond. B Biol. Sci. 361, 1837-1842. doi: 10.1098/rstb.2006.1907

Suenaga, H., Ohnuki, T., and Miyazaki, K. (2007). Functional screening of a metagenomic library for genes involved in microbial degradation of aromatic compounds. Environ. Microbiol. 9, 2289-2297. doi: 10.1111/j.14622920.2007.01342.x

Sun, M. Z., Zheng, H. C., Meng, L. C., Sun, J. S., Song, H., Bao, Y. J., et al. (2015). Direct cloning, expression of a thermostable xylanase gene from the metagenomic DNA of cow dung compost and enzymatic production of xylooligosaccharides from corncob. Biotechnol. Lett. 37, 1877-1886. doi: 10.1007/s10529-015-1857-6

Sundarram, A., Pandurangappa, T., and Murthy, K. (2014). $\alpha$-amylase production and applications: a review. J. Appl. Environ. Microbiol. 2, 166-175. doi: 10.12691/jaem-2-4-10

Sundberg, C., Al-Soud, W. A., Larsson, M., Alm, E., Yekta, S. S., Svensson, B. H., et al. (2013). 454 pyrosequencing analyses of bacterial and archaeal richness in 21 full-scale biogas digesters. FEMS Microbiol. Ecol. 85, 612-626. doi: 10.1111/1574-6941.12148

Tan, H., Mooij, M. J., Barret, M., Hegarty, P. M., Harington, C., Dobson, A. D. W., et al. (2014). Identification of novel phytase genes from an agricultural soil-derived metagenome. J. Microbiol. Biotechnol. 24, 113-118. doi: $10.4014 / \mathrm{jmb} .1307 .07007$

Tan, H., Wu, X., Xie, L., and Huang, Z. (2016). Identification and characterization of a mesophilic phytase highly resilient to high-temperatures from a fungusgarden associated metagenome. Appl. Microbiol. Biotechnol. 100, 2225-2241. doi: $10.1007 / \mathrm{s} 00253-015-7097-9$

Tekere, M., Lötter, A., Olivier, J., Jonker, N., and Venter, S. (2011). Metagenomic analysis of bacterial diversity of Siloam hot water spring, Limpopo, South Africa. African J. Biotechnol. 10, 18005-18012. doi: 10.5897/AJB11.899

Tsudome, M., Deguchi, S., Tsujii, K., Ito, S., and Horikoshi, K. (2009). Versatile solidified nanofibrous cellulose-containing media for growth of extremophiles. Appl. Environ. Microbiol. 75, 4616-4619. doi: 10.1128/AEM.00519-09

Uchiyama, T., and Miyazaki, K. (2009). Functional metagenomics for enzyme discovery: challenges to efficient screening. Curr. Opin. Biotechnol. 20, 616-622. doi: 10.1016/j.copbio.2009.09.010

Ufarté, L., Potocki-Veronese, G., and Laville, É. (2015). Discovery of new protein families and functions: new challenges in functional metagenomics for biotechnologies and microbial ecology. Front. Microbiol. 6:563. doi: 10.3389/fmicb.2015.00563

Urbieta, M. S., Donati, E. R., Chan, K. G., Shahar, S., Sin, L. L., and Goh, K. M. (2015). Thermophiles in the genomic era: biodiversity, science, and applications. Biotechnol. Adv. 33, 633-647. doi: 10.1016/j.biotechadv.2015.04.007

van Dijk, E. L., Auger, H., Jaszczyszyn, Y., and Thermes, C. (2014). Ten years of next-generation sequencing technology. Trends Genet. 30, 418-426. doi: 10.1016/j.tig.2014.07.001

de Vasconcellos, S. P., Angolini, C. F. F., García, I. N. S., Martins Dellagnezze, B., da Silva, C. C., Marsaioli, A. J., et al. (2010). Screening for hydrocarbon biodegraders in a metagenomic clone library derived from Brazilian petroleum reservoirs. Org. Geochem. 41, 1067-1073. doi: 10.1016/j.orggeochem.2010.08.003

Verma, D., Kawarabayasi, Y., Miyazaki, K., and Satyanarayana, T. (2013). Cloning, expression and characteristics of a novel alkalistable and thermostable xylanase encoding gene (Mxyl) retrieved from compost-soil metagenome. PLoS ONE 8:e52459. doi: 10.1371/journal.pone.0052459
Verma, D., and Satyanarayana, T. (2013). Improvement in thermostability of metagenomic GH11 endoxylanase (Mxyl) by site-directed mutagenesis and its applicability in paper pulp bleaching process. J. Ind. Microbiol. Biotechnol. 40, 1373-1381. doi: 10.1007/s10295-013-1347-6

Vidal-Melgosa, S., Pedersen, H. L., Schückel, J., Arnal, G., Dumon, C., Amby, D. B., et al. (2015). A new versatile microarray-based method for high throughput screening of carbohydrate-active enzymes. J. Biol. Chem. 290, 9020-9036. doi: $10.1074 /$ jbc.M114.630673

Vidya, J., Swaroop, S., Singh, S., Alex, D., Sukumaran, R., and Pandey, A. (2011). Isolation and characterization of a novel $\alpha$-amylase from a metagenomic library of Western Ghats of Kerala, India. Biologia 66, 939-944. doi: 10.2478/s11756011-0126-y

Wagner, I. D., and Wiegel, J. (2008). Diversity of thermophilic anaerobes. Ann. N.Y. Acad. Sci. 1125, 1-43. doi: 10.1196/annals.1419.029

Wang, C., Dong, D., Wang, H., Müller, K., Qin, Y., Wang, H., et al. (2016). Metagenomic analysis of microbial consortia enriched from compost: new insights into the role of Actinobacteria in lignocellulose decomposition. Biotechnol. Biofuels 9:22. doi: 10.1186/s13068-016-0440-2

Wang, H., Gong, Y., Xie, W., Xiao, W., Wang, J., Zheng, Y., et al. (2011). Identification and characterization of a novel thermostable gh-57 gene from metagenomic fosmid library of the juan de fuca ridge hydrothemal vent. Appl. Biochem. Biotechnol. 164, 1323-1338. doi: 10.1007/s12010-0119215-1

Wang, M., Lai, G. L., Nie, Y., Geng, S., Liu, L., Zhu, B., et al. (2015). Synergistic function of four novel thermostable glycoside hydrolases from a long-term enriched thermophilic methanogenic digester. Front. Microbiol. 6:509. doi: $10.3389 /$ fmicb. 2015.00509

Wang, S. D, Guo, G. S., Li, L., Cao, L. C., Tong, L., Ren, G. H., et al. (2014). Identification and characterization of an unusual glycosyltransferaselike enzyme with $\beta$-galactosidase activity from a soil metagenomic library. Enzyme Microb. Technol. 57, 26-35. doi: 10.1016/j.enzmictec.2014.01.007

Wang, S., Wang, K., Li, L., and Liu, Y. (2013). Isolation and characterization of a novel organic solvent-tolerant and halotolerant esterase from a soil metagenomic library. J. Mol. Catal. B Enzym. 95, 1-8. doi: 10.1016/j.molcatb.2013.05.015

Wang, Y., and Qian, P. Y. (2009). Conservative fragments in bacterial 16S rRNA genes and primer design for $16 \mathrm{~S}$ ribosomal DNA amplicons in metagenomic studies. PLoS ONE 4:e7401. doi: 10.1371/journal.pone.0007401

Wemheuer, B., Taube, R., Akyol, P., Wemheuer, F., and Daniel, R. (2013). Microbial diversity and biochemical potential encoded by thermal spring metagenomes derived from the Kamchatka peninsula. Archaea 2013:136714. doi: $10.1155 / 2013 / 136714$

Wierzbicka-Woś, A., Bartasun, P., Cieśliński, H., and Kur, J. (2013). Cloning and characterization of a novel cold-active glycoside hydrolase family 1 enzyme with $\beta$-glucosidase, $\beta$-fucosidase and $\beta$-galactosidase activities. BMC Biotechnol. 13:22. doi: 10.1186/1472-6750-13-22

Wilson, M. S., Siering, P. L., White, C. L., Hauser, M. E., and Bartles, A. N. (2008). Novel archaea and bacteria dominate stable microbial communities in North America’s largest hot spring. Microb. Ecol. 56, 292-305. doi: 10.1007/s00248007-9347-6

Wu, M., and Scott, A. J. (2012). Phylogenomic analysis of bacterial and archaeal sequences with AMPHORA2. Bioinformatics 28, 1033-1034. doi: 10.1093/bioinformatics/bts079

Xie, W., Wang, F., Guo, L., Chen, Z., Sievert, S. M., Meng, J., et al. (2011). Comparative metagenomics of microbial communities inhabiting deep-sea hydrothermal vent chimneys with contrasting chemistries. ISME J. 5, 414-426. doi: 10.1038/ismej.2010.144

Yap, W. H., Zhang, Z., and Wang, Y. (1999). Distinct types of rRNA operons exist in the genome of the actinomycete Thermomonospora chromogena and evidence for horizontal transfer of an entire rRNA operon. J. Bacteriol. 181, 5201-5209.

Ye, M., Li, G., Liang, W. Q., and Liu, Y. H. (2010). Molecular cloning and characterization of a novel metagenome-derived multicopper oxidase with alkaline laccase activity and highly soluble expression. Appl. Microbiol. Biotechnol. 87, 1023-1031. doi: 10.1007/s00253-010-2507-5

Zamora, M. A., Pinzón, A., Zambrano, M. M., Restrepo, S., Broadbelt, L. J., Moura, M., et al. (2015). A comparison between functional frequency and metabolic flows framed by biogeochemical cycles in metagenomes: the case 
of "El Coquito" hot spring located at Colombia’s national Nevados park. Ecol. Modell. 313, 259-265. doi: 10.1016/j.ecolmodel.2015.06.041

Zhang, X., Li, H., Li, C.-J., Ma, T., Li, G., and Liu, Y.-H. (2013). Metagenomic approach for the isolation of a thermostable $\beta$-galactosidase with high tolerance of galactose and glucose from soil samples of Turpan Basin. BMC Microbiol. 13:237. doi: 10.1186/1471-2180-13-237

Zhou, J., Bruns, M. A., and Tiedje, J. M. (1996). DNA recovery from soils of diverse composition. Appl. Environ. Microbiol. 62, 316-322.

Zhu, Y., Li, J., Cai, H., Ni, H., Xiao, A., and Hou, L. (2013). Characterization of a new and thermostable esterase from a metagenomic library. Microbiol. Res. 168, 589-597. doi: 10.1016/j.micres.2013.04.004
Conflict of Interest Statement: The authors declare that the research was conducted in the absence of any commercial or financial relationships that could be construed as a potential conflict of interest.

Copyright (๑) 2016 DeCastro, Rodríguez-Belmonte and González-Siso. This is an open-access article distributed under the terms of the Creative Commons Attribution License (CC BY). The use, distribution or reproduction in other forums is permitted, provided the original author(s) or licensor are credited and that the original publication in this journal is cited, in accordance with accepted academic practice. No use, distribution or reproduction is permitted which does not comply with these terms. 